\title{
ELECCIONES AL PARLAMENTO VASCO DEL 23 DE OCTUBRE DE 1994
}

\author{
Ignacio María Beobide Ezpeleta
}

\section{INTRODUCCION}

El 23 de octubre de 1994 se celebraron las quintas Elecciones Autonómicas al Parlamento Vasco. Las anteriores habían tenido lugar los años 1980, 1984, 1986 y 1990. Los Partidos nacionalistas alcanzaron un total de 41 de los 75 escaños parlamentarios; el Partido Nacionalista Vasco, 22; Eusko Alkartasuna, 8, y Herri Batasuna, 11. Los votos nacionalistas fueron 574.122 frente a los 442.753 no nacionalistas con una abstención de casi el $40 \%$. Se trataba de la citra nacionalista más baja en unas elecciones autonómicas. En comparación con las Elecciones de 1990 se habían perdido tres escaños parlamentarios (Eusko Alkartasuna, 1, y Herri Batasuna, 2) y casi 97.000 votos $^{1}$, aunque ha de tenerse en cuenta la fusión de Euskadiko Ezkerra con el Partido Socialista.

Este trabajo no pretende analizar los resultados electorales, sino la campaña de los Partidos nacionalistas y, más en concreto, el contenido o mensaje dirigido a los electores tanto desde un punto de vista cualitativo como cuantitativo, siguiendo una metodología ya utilizada en anteriores trabajos ${ }^{2}$.

1 Ver: Elecciones al Parlamento Vasco 23-X-94, Gobierno Vasco, Departamento de Interior, pp. 18 y 19.

2 Ver mi trabajo «Elecciones Generales del 6 de junio de 1993. La campaña de los Partidos Nacionalistas Vascos», Revista Estudios de Deusto, vol. 41/2, julio-diciembre 1993, pp. 9 y 10 y los trabajos citados en la nota 1 . En este estudio utilizo como fuente la siguiente prensa diaria en su edición para Bizkaia: El Correo Español-El Pueblo Vasco, Deia, Egin, El Mundo del País Vasco y El País. La información de los distintos diarios es muy similar y no ofrece variaciones cualitativas, aunque sí cuantitativas, si se exceptúa a El País, que hizo un seguimiento muy pobre de la campaña. Dada la diferencia cuantitativa de atención, las mediciones, por razones de homogeneidad, se han hecho de acuerdo con los datos ofrecidos por El Correo y para ello únicamente se han tenido en cuenta las intervenciones directas de los partícipes en la campaña (v.g. en mítines, conferencias, entrevistas, declaraciones, mesas redondas). 
Cada campaña es analizada por separado, siguiendo un mismo esquema general, que distingue los datos básicos, la definición del Partido a través de su nacionalismo, cuestiones programáticas no nacionalistas y Gobierno de la Comunidad Autónoma, y, por último, la actitud ante los demás Partidos contendientes en la campaña.

De manera general se puede decir que la campaña tuvo una configuración, en buena medida, ideológica en el fondo y en la forma. En el fondo, porque lo que se quiso transmitir al electorado fue la creencia en la utilidad y necesidad de las ideas y mitos nacionalistas. Así, por ejemplo, aunque la autodeterminación fue interpretada de manera distinta por cada Partido Político, todos la incluyeron como parte fundamental de su ideario político. Lo mismo ocurrió con los conceptos de libertad nacional, soberanía o independencia. La insistencia en la necesidad de más nacionalismo o de un nacionalismo auténtico para Euskadi no sólo obedecía a razones electorales (más nacionalismo significaba más poder para el o los Partidos nacionalistas), sino que surgía de la convicción o del temor de que la sociedad vasca estaba perdiendo confianza en el sentido, eficacia y funcionalidad del nacionalismo. La insistencia en los temas esencialmente nacionalistas parecía responder a una interpretación creciente en la sociedad del carácter utópico del nacionalismo vasco. En este sentido puede decirse que la campaña nacionalista reflejaba la confluencia de dos nacionalismos, el nacionalismo de Partido, con grandes dosis de nacionalismo individual, y el nacionalismo social.

A este planteamiento ideológico obedeció, en primer lugar, la utilización en la campaña del binomio españolismo-vasquismo, es decir, la repetición constante de la diferencia y oposición entre lo español y lo vasco. Más explícita que implícitamente el esquema identidad-diferencia fue un argumento electoral y un intento de reanimación de la conciencia nacionalista.

En segundo lugar, hay que destacar la descalificación entre nacionalistas como parte de esta cuestión de fondo ideológica, siendo en algunos casos la argumentación básica de la campaña. El fantasma de la autenticidad nacionalista presidió las críticas entre nacionalistas, por más que algunos reconociesen el hecho de la variedad de nacionalismos. La peor parte se la llevó, por ser Partido de Gobierno, el PNV, pero alcanzó a todos. La descalificación tuvo diversas versiones en un abanico, que iba desde la acusación de pérdida del carácter nacionalista y de utilización del mismo para conquistar el poder político y social en un caso (PNV) hasta la negación de la justificación de su mera existencia en otro (EA), pasando por la denuncia del carácter artificial y postizo de un tercer nacionalismo (HB). Aunque estas críticas y rechazos se hicieron, también, en nombre de una variable ideológica de clase - conservadurismo, inte- 
grismo, socialdemocracia y populismo socialista- la cuestión de fondo fue un argumento nacionalista, siendo éstas otras razones, en bastantes casos, argumentos complementarios o, simplemente, cuestiones de pura imagen electoral. No cabe decir lo mismo del rechazo manifiesto e inequívoco de la estrategia de la violencia seguida por ETA, que hicieron el PNV y EA.

Y en tercer lugar, en torno a los conceptos de Euskadi vertebrada e invertebrada (dimensión institucional de la ideología) se desarrolló la parte más novedosa de la campaña y, a la vez, la parte más alarmante desde el punto de vista nacionalista. Frente a las tesis nacionalistas de la unidad política y social de Euskal Herria, cuya articulación era entendida de forma diversa por los tres partidos, surgió la conciencia, y el temor, de que había fuertes grupos sociales a los que respondían Partidos políticos de ámbito territorial, como Unidad Alavesa (que había sacado tres parlamentarios en 1990, sacó 5 parlamentarios en 19943) y otros, cuya creación se temía, que ponían en cuestión el Estatuto de Autonomía, único fundamento jurídico-político, junto con la Constitución, que había permitido la actual articulación política de Euskadi. Desde tales Partidos de ámbito territorial se ponía en cuestión la unidad de Euskadi, el Estatuto de Autonomía y todos los intentos de lograr una homogeneidad social, cultural y lingüística. La consolidación, además de otros factores, de Partidos Políticos contrarios al sistema político autonómico por la derecha de los Partidos sustentadores del mismo, se sumaría a la actitud antisistema de Herri Batasuna por la izquierda, dando lugar con ello a un sistema de Partidos políticos, que autores como Sartori han denominado de pluralismo polarizado. Tal Sistema de Partidos daría lugar a un sistema político difícilmente viable 4 . Con ello podría ponerse en cuestión la apuesta nacionalista por la autonomía. La campaña expresa estos temores nacionalistas, que se hicieron mayores ante la expectativa de una fuerte abstención, como así ocurrió.

La campaña fue, también en la forma, ideológica, ya que los métodos utilizados de comunicación entre dirigentes y electores fueron esencialmente los propios de toda interiorización mecánica e irreflexiva. La inculcación, otras veces mencionada en anteriores trabajos, se repitió, como no podía ser menos, en la última campaña.

De todos modos, es de destacar el esfuerzo de algunos dirigentes políticos, no de todos, por racionalizar el discurso político tratando de exponer las posibilidades que la Constitución de 1978, a través de la Primera

3 Ver Elecciones al Parlamento Vasco, ya citado.

4 Ver Partidos y sistemas de partidos 1, Giovanni SARToRI; Alianza Universidad, pp. 165 y ss. 
Disposición Adicional y del artículo 150, y el Estatuto de Guernica, a través de su Disposición Adicional, abrían a los nacionalistas para realizar una nueva versión de conceptos clásicos como el autogobierno o la autodeterminación. El mismo esfuerzo se observó en torno al concepto de cultura vasca, donde se defendió la idea de mestizaje.

El nacionalismo social más fuerte caminaba por esta senda, aunque hay que destacar que la racionalización de este discurso político era muy incompleta, como lo demuestran las titubeantes o lamentables declaraciones en torno a la Constitución y al Rey, que se recogen en este trabajo.

\section{LA CAMPAÑA DEL PARTIDO NACIONALISTA VASCO}

\section{Datos básicos}

La definición de las características de Partido ocupó el 56\% de la campaña; la crítica de los demás Partidos Políticos, el resto.

En el apartado de definición de la imagen de Partido, los componentes nacionalistas tales como el concepto de nación vasca, la construcción nacional, la renovación del nacionalismo, la independencia, la radicalización del mensaje nacionalista, la autodeterminación, el autogobierno y el Estatatuto de Autonomía llenaron el 27,48\% del espacio, lo que equivalía a un $15,24 \%$ del total de la campaña. Sólo los temas del Estatuto Vasco con un $11 \%$ y de la construcción de la nación vasca con casi un 9\% del total de la imagen destacaron en la presentación de la ideología nacionalista.

Los contenidos programáticos no nacionalistas alcanzaron la cota más importante con el $38,56 \%$, que representaba un $21,39 \%$ del total de la campaña. La defensa de los Partidos Políticos y de la clase política, la llamada al voto responsable, la corrupción, el Estado de Bienestar, los logros del PNV, el anuncio de un futuro esperanzador para el mundo empresarial y el Pacto de Ajuria Enea con su concomitante, la reinserción de los violentos, fueron los contenidos de este subapartado. Fue el Pacto de Ajuria Enea el tema más prolijamente tratado, alcanzando el 22,28\% de la imagen de Partido, es decir, un 12,36\% de la campaña. Entre los demás sólo cabe destacar lo dicho en defensa del sistema político, 6,12\% y sobre el Estado de Bienestar, que alcanzó un 5\%, que se convierte en un $3,39 \%$ y $2,8 \%$, cantidades irrelevantes en el conjunto de la campaña.

Las cuestiones de praxis política se concretaron en el Gobierno autonómico postelectoral, coaliciones, desbloqueo de la situación política de Gipuzkoa, hegemonía del PNV y relaciones entre Ardanza y Arzalluz, que parecían ocultar, me refiero a éstas últimas, el problema de las rela- 
ciones institucionales entre Gobierno y Partido. Del 33,94\% dedicado a contenidos de praxis política, el futuro gobierno de coalición fue el punto más tratado con el 19,28\%, que representa un $10,69 \%$ de la campaña. Entre las demás cuestiones, sólo lo relativo a las relaciones entre Ardanza y Arzalluz tuvo alguna pequeña relevancia $(6,7 \%)$.

Por lo que respecta a la atención prestada a los Partidos Políticos, ésta alcanzó el $44 \%$ de la campaña. Por orden decreciente aparece la siguiente configuración: Partido Socialista de Euskadi-EE con el 33,09\% (14,73\% del total de campaña), Unidad Alavesa con el 23,74\% (10,57\%), Partido Popular con el 21,29\% (9,48\%), ETA-Herri Batasuna con el $17,12 \%(7,62 \%)$, Izquierda Unida con el 4,31\% (1,92\%) y Eusko Alkartasuna con el $0,43 \%(0,19 \%)$.

Los políticos que intervinieron en la campaña, según destaca la versión para Bizkaia de la prensa utilizada, fueron Ardanza con el 49,28\%, Arzalluz con el 21,02\%, Egibar con el 16,88\%, Atutxa con el 6,85\% y Arregui con el 3,36\%. Otros miembros del Partido Nacionalista Vasco aparecen con tantos por cientos muy pequeños de participación ${ }^{5}$.

\section{Desarrollo de la campaña}

\section{A) La definición o imagen de Partido}

\section{La ideología nacionalista}

Estatuto y autogobierno fueron los temas más recurridos de este apartado. Entre los dos suman la mitad del espacio, siendo el primero el más frecuente. El tema del Estatuto estuvo presente durante toda la campaña, hablándose de él lo mismo el primer día que el último, a diferencia de otros temas, cuya presencia es únicamente ocasional o muy circunstancial.

El Estatuto servía no sólo para identificar la política positiva del PNV en su defensa, sino también para criticar al Gobierno socialista por el incumplimiento de su culminación después de haber pasado quince años desde su aprobación y, además, para anunciar que los objetivos políticos nacionalistas iban más allá del mismo. El Estatuto de Autonomía no era el fin del trayecto político, sino un paso hacia él; en este sentido se interpretaba la Disposición Adicional del Estatuto. Aunque no se especificaba el contenido de la Disposición Adicional, se reconocía en ella una «vía de potencial político para explorar mecanismos de negociación

\footnotetext{
${ }^{5}$ El tanto por ciento de cada participante no se refiere al número de intervenciones, sino a la cantidad de espacio que la prensa le atribuye.
} 
en virtud de lo que el pueblo vasco» demandase ${ }^{6}$. La incertidumbre resultante de tal modo de expresarse se apaciguaba un tanto, aunque no mucho, al sostener que la única alternativa al texto del Estatuto era «más Estatuto» ${ }^{7}$. En su afán de ver cumplido definitivamente el contenido normativo del mismo, el PNV estaba «dispuesto a aceptar la interpretación que el PSOE hacía del Estatuto en 1980»8. Había que terminar de una vez con el debate estatutario completando el proceso de transferencias, porque su incumplimiento sería un fraude para la sociedad vasca ${ }^{9}$. Ese era un objetivo para la próxima legislatura. En el supuesto de su incumplimiento Ardanza se remitía a la voluntad popular: « $¡ A$ ver qué dice el pueblo cuando se haya cansado de ver imcumplido en su totalidad el pacto que le recomendamos refrendar!» 10 .

Ya al final de la campaña, el Lehendakari en funciones, preguntado en una entrevista sobre los pasos que iba a dar el PNV ante el derecho de autodeterminación, respondió de una manera que resumía tanto el criterio nacionalista sobre el Estatuto y la necesidad de superarlo como, tal vez, sobre su concepto de autodeterminación, al decir que «en este momento lo que pedimos es seriedad y que se cumpla el pacto estatutario. Pretendo que la próxima legislatura se cumpla la parte dispositiva del Estatuto, que se nos den las materias que nos corresponden. Cumplido eso lo que nos plantearemos claramente es que el artículo primero del Estatuto dice que Euskadi es una nación y que la territorialidad de Euskadi no es sólo Alava, Guipúzcoa y Vizcaya sino, también, en su caso Navarra, siempre contando con la voluntad de los navarros. Luego hay una previ-

6 Correo 9, 26; Deia 9, 6. La primera cifra indica el día; la segunda la página. Todos los periódicos son del mes de octubre de 1994, datos que se dan por supuesto en toda cita, a menos que expresamente se haga constar otra cosa. A excepción de El País, lo habitual es que los periódicos aquí utilizados informen, bien en el mismo día o bien al día siguiente, de los mismos hechos, aunque la calidad y la amplitud sea distinta, por lo que la utilización de varios periódicos resulta complementaria. El hecho de que en cada información no se citen todos los periódicos no quiere decir que los no citados no informen sobre la cuestión, sino que no añaden nada nuevo.

7 Correo 11, 17. Ver: Deia 11,4.

8 Correo 8, 15. Ver, también, Deia 8, 1 y 4. Esta opinión fue defendida en diversas ocasiones.

9 Deia 17, 5. Fue Ardanza el que más trató el tema estatutario, acompañado de Egibar. Ver Egin 8, 13, donde se lee: «Cuantos más años pasen sin que se cumpla el Estatuto, mayor va a ser la frustración y la deslegitimación de los pactos, porque ¿qué credibilidad pueden tener unos pactos debatidos, firmados, refrendados y defendidos ante el pueblo, que luego no se cumplen?».

10 Correo 22, 19. Ver Deia 22, 4. Un argumento utilizado para exigir la culminación del Estatuto era que los ciudadanos vascos preferían que las competencias estuviesen en manos del Gobierno Vasco tal como expresamente se concretaba en el caso del ansiado traspaso de la Seguridad Social. (Ver Deia 9, 6). 
sión constitucional de que materias de competencia del Estado son transferibles. ¿Cuándo podemos empezar a hablar de eso, o es sólo un adorno? Además el Estatuto termina diciendo que su aceptación no supone renuncia alguna a los derechos que pudieran corresponder a este pueblo. Teóricamente, el Estatuto no se termina nunca» ${ }^{11}$.

Joseba Egibar pensaba que con la culminación del Estatuto sólo terminaba el Estatuto, quedando entre otros instrumentos la Disposición Adicional de la Constitución sobre los derechos históricos del pueblo vasco. «¿Por qué — se preguntaba, aludiendo al Partido Popular- no vamos a poder explorar, por caminos legales, mecanismos de negociación más allá del Estatuto?»12.

La racionalización que manifestaba semejante estrategia política no respondía a un nuevo concepto de nacionalismo, sino que se hacía coincidir con las tesis más añejas del nacionalismo sobre la Constitución o el Rey. Cuando se le preguntó a Ardanza si era leal a la Constitución, respondió: «¿Por qué tengo que ser leal a la Constitución? ¿Por qué tengo que ser leal a tantas y tantas cosas con las cuales yo no me he comprometido? Yo no debo lealtad a nada con lo cual yo no me he comprometido como persona o como partido. Otra cosa es que como demócrata, aunque yo no le deba lealtad, sí deba el respeto. Lo que a mí me sorprende es que nos pidan lealtades quienes sí se comprometieron con la Constitución y, sin embargo, luego no la cumplen en muchas ocasiones. Eso sí que es auténticamente contradictorio» ${ }^{13}$. Y preguntado el mismo Ardanza sobre si Don Juan Carlos era también su rey, respondió: «Don Juan Carlos es el Rey de España. Yo no soy monárquico, pero respeto esa Institución. Nunca me he puesto a cuestionarme si es mi Rey o no es mi Rey. Yo no tengo Rey, pero respeto que exista. Está consensuado, no pierdo medio minuto en pensarlo» ${ }^{14}$.

El autogobierno fue otro de los conceptos más utilizados. Lo mismo había ocurrido en anteriores campañas. La ocasión más frecuente de su utilización coincidió con el tema del Estatuto, si bien fue mencionado en otras circunstancias y, aunque en ningún momento se dijo explícitamente que el autogobierno era un concepto innecesario, que no añadía nada al modo de entender el Estatuto por los nacionalistas del PNV, sí es cierto que el autogobierno se hizo coincidir con el Estatuto, con su culminación

11 Correo 21, 26. El Correo destacó la afirmación nacionalista de que «quieren que renunciemos a la autodeterminación, a su ejercicio y no lo vamos a hacer. Franco no logró domarnos y éstos tampoco» (Correo 20,19).

12 Deia $9,6$.

13 El Mundo del País Vasco 21, 10.

14 El Mundo del País Vasco 21, 11. 
y con su futura ampliación. Pero se aseguró que en materia de autogobierno el PNV nunca traspasaría «los límites de la voluntad popular»15. Esto supuesto, y en una línea muy propia de todo nacionalismo por moderado que sea, se defendió el autogobierno por su eficacia y utilidad en la solución de los problemas de la sociedad vasca, que requería una proximidad de los centros de decisión. Problemas fundamentales como el declive industrial, se dijo expresamente, no podían ser resueltos a distancia ${ }^{16}$.

El PNV también utilizó durante la campaña el término autodeterminación, concepto que, si bien en su sentido original y genuino no puede ser considerado como exclusivamente nacionalista ${ }^{17}$, es, sin embargo, junto al de independencia y sus equivalentes, pieza clave de todos los nacionalismos. En boca de los nacionalistas del PNV, interesados en conseguir votos, tiene un contenido bastante más suave que el propio de la historia del pensamiento político o el de los movimientos de emancipación del tercer mundo o el de la desconolización. En concreto, el derecho a la autodeterminación del pueblo vasco lo proclamó Arzalluz como algo irrenunciable, tan irrenunciable como la libertad individual lo era para la persona $^{18}$, en respuesta a la pretensión de los máximos representantes del PSOE y PP, que, según interpretación del propio Arzalluz, pretendían que los vascos nacionalistas renunciasen a su nacionalismo y renunciasen a expresar que su única patria era Euskadi19. Egibar lo comparó con el derecho a la vida de las personas físicas, por lo que no hacía falta demostrar su existencia ${ }^{20}$. También mencionó la autodeterminación Atutxa, cuando defendió que el programa del PNV era netamente abertzale y se fundamentaba en los pilares de la paz, trabajo por y para Euskadi, lealtad hacia sus votantes y autodeterminación ${ }^{21}$. En estas intervenciones la pro-

15 Correo 10, 15.

16 Ver: Deia 9, 6; Correo 11, 17; Deia 16, 11; 17, 5; $20,7$.

17 La autodeterminación era un contenido del Programa electoral de Izquierda Unida (Ver v.g. El País 22, 16) y lo fue del Partido Comunista de Euskadi al final de la II República Española (Ver mi trabajo «La cuestión nacional vasca en la prensa socialista y comunista de Bilbao (1936-1937)», Estudios de Deusto, Vol. XXVIII/2, julio-diciembre 1980, pp. 313-345).

18 Como es sabido la obra de Elie Kedourie, Nationalism (Hutchinson University Library, London, 1979) es una crítica de la extensión (tan característica de la ideología nacionalista) del concepto de autodeterminación individual a un ente colectivo como la nación o pueblo. Otra parecida interpretación es la que hizo Joseba Egibar (Deia 21, 4) al decir que «el derecho de autodeterminación es a los pueblos como el derecho a la vida a las personas, por lo tanto no tenemos que demostrar la existencia de ese derecho».

19 Deia $16,8$.

20 Deia $21,4$.

21 Deia 16, 11. Según Ardanza, los ejes del programa del PNV eran la competitividad, la solidaridad, el autogobierno y la reconciliación (Ver Deia 16, 4). 
clamación del derecho a la autodeterminación se dejaba en la incertidumbre de lo abstracto e impreciso.

La primera especificación del modo de entender la autodeterminación la hizo Ardanza al contestar a la pregunta del entrevistador sobre el tema en cuestión, remitiéndole a una interpretación jurídica y política del Estatuto de Autonomía y de la propia Constitución Española de 1978, tal como se ha indicado más arriba al hablar del Estatuto.

Una segunda interpretación de la autodeterminación la hizo el propio Egibar en un debate radiofónico con Oliveri, cuando especificó que una cosa era el reconocimiento de tal derecho y «otra cosa es por dónde pasa el ejercicio de ese derecho y el PNV lo ha definido ya años atrás, porque entiende que ese ejercicio paulatino del derecho de autodeterminación pasa de un modo gradual y democrático por lo que puede ser la integración territorial, y el fortalecimiento político, económico y cultural de este país» ${ }^{22}$. Esta respuesta coincidía y completaba la interpretación dada por Ardanza. El nacionalismo del PNV se movía así en una estrategia continuista y gradual, ajena al sentido rupturista propio del concepto de autodeterminación, que se resumía en expresiones como «se puede renunciar a ejercer la autodeterminación, pero no al derecho» 0 «somos gente idealista que nos hemos pragmatizado», aunque se afirmase, a la vez, que «quieren que renunciemos a la autodeterminación, a su ejercicio y no lo vamos a hacer. Franco no logró domarnos y éstos tampoco»23.

En este contexto, las palabras de Arzalluz dichas en Amurrio, «si por mí fuera, tendríamos la independencia mañana, mejor que pasado mañana 24,0 las dichas en Eibar al comienzo de la campaña, «el derecho de autodeterminación es un derecho al que no se renuncia y consiste en optar por una España federal, confederal o la independencia, y es el pueblo el que tiene que decirlo, no el $\mathrm{PNV}$ », eran la obligada lectura del memorándum nacionalista ante una política pragmática y ante unas circunstancias especiales, que puede sugerir distintas interpretaciones, menos la literal. Se habló muy poco de independencia al comienzo de la campaña, para desaparecer después de la propaganda nacionalista.

Más importancia y mayor desarrollo tuvo el tema de la construcción nacional, como corresponde a un Partido que, casi desde el principio de su andadura política, estableció la prioridad de la recuperación del ser de la nación vasca sobre la libertad e independencia de la misma ${ }^{25}$.

22 Deia $21,4$.

23 Correo 10, 15 y 20, 19.

${ }^{24}$ Deia $9,6$.

25 Ver mi trabajo «Nacionalismo Vasco: Nación y poder», Estudios de Deusto, Vol. 41/1, enero-junio 1993, pp. 9-90, especialmente pp. 23-32. 
Ardanza y Egibar desarrollaron dos aspectos relativos a esta cuestión. El primero insistió en que el objetivo del PNV era un proyecto de construcción de la nación vasca, abierto al mundo, que representaba el camino más directo para conseguir tanto una sociedad vasca integrada, abierta y democrática como la renovación del mismo nacionalismo. Se partía del reconocimiento de que el País Vasco era fruto de un mestizaje cultural secular o milenario, donde convivían yuxtapuestas la cultura autóctona y la castellana. El hecho de que no se hubiese asumido social y subjetivamente semejante fenómeno de mestizaje acarreaba como consecuencias una conciencia social fragmentada, una ausencia de identidad y pertenencia común y un déficit de integración. El proyecto nacionalista intentaba la integración social y nacional basada en la libre adhesión a un proyecto de integración entendido como «la resultante enriquecida y enriquecedora de un mestizaje cultural objetivamente reconocido y subjetivamente asumido». Los dos instrumentos importantes para realizar la construcción nacional integrada eran el Estatuto de Autonomía y la educación. El sistema educativo, en concreto, se consideraba fundamental para crear la conciencia nacional, sin caer en el adoctrinamiento, porque permitiría hacer de puente entre las diferentes sensibilidades y crear sentimientos de identidad y pertenencia común ${ }^{26}$. Ardanza destacó que en el objetivo de construcción nacional «no chocamos tanto con obstáculos externos como con nosotros mismos, con nuestras capacidades y con nuestras deficiencias, con nuestros aciertos y nuestros errores» ${ }^{27}$.

La construcción nacional, así especificada, se enmarcaba en una concepción clásica de la nación al decir que «entre ser una nación o construir día a día la nación, hay una relación dinámica que, al margen de la reivindicación de un determinado status político-jurídico ante terceros, hace referencia a la consolidación y al reforzamiento de esa red interior de lazos, que otorga a un determinado colectivo de ciudadanos su carácter nacional», red constituida por «la lengua, las expresiones culturales, la organización política, familiar... y por un elemento de subjetividad, la conciencia, que confiere a la nación su carácter dinámico» 28 .

La renovación y recomposición del nacionalismo vasco debía hacerse con «respeto a la pluralidad como riqueza de Euskadi» 29 . En este sentido era necesaria la normalización del euskera y el mantenimiento de las

${ }_{26}$ Deia 15, 7 y Correo 15, 21. La información periodística era bastante deficiente en este caso.

27 El Mundo del País Vasco, 15, 14.

28 El Mundo del País Vasco 15, 14. Ver, también El País 21, 28, donde Ardanza distingue entre la nación vasca y la nación española.

29 Deia $15,5$. 
estructuras deportivas, porque una sociedad sin cultura, educación y deporte, sentenció Joseba Arregi, carecía de identidad y se convertía «en juguete pasivo del devenir histórico» ${ }^{30}$.

El segundo aspecto del proyecto de construcción nacional del PNV lo desarrolló Egibar, quien insistió en que sólo era factible con la adhesión pacífica y voluntaria de los ciudadanos vascos, que se identificaba con el apoyo electoral al PNV. La construcción nacional exigía la superación de la crisis económica y, para ello, la solidaridad intergeneracional, el desarrollo de la competitividad, la creación por parte de los políticos de las condiciones adecuadas para las empresas, el apoyo a las empresas con futuro, la solidaridad sectorial (donde se emitían acusaciones de insolidaridad contra los sectores empleados en la Administración dependientes de los presupuestos públicos, que mostraban, dicho sea de paso, un tanto de ignorancia y mucho de hipocresía), o la posible renuncia a los derechos adquiridos para dejar hueco a los 80.000 jóvenes en paro, «porque, ¿quién va a soportar el día de mañana los elevados costes de nuestros derechos adquiridos?» Estos planteamientos eran parte de una cultura social de compromiso y corresponsabilidad, que afectaba de manera especial a los nacionalistas, "porque todo esto también es construcción nacional». El objetivo nacionalista era una Euskadi mejor con un lugar propio en la nueva Europa ${ }^{31}$.

La construcción nacional necesitaba, por otra parte, la integración territorial en Euskadi de Villaverde de Trucíos y del Condado de Trebiño, además de Navarra ${ }^{32}$.

El PNV no sólo defendía que tenía un proyecto integrador y vertebrador del País Vasco, sino que era el único que existía y el único que podía realizarse, porque «la columna vertebral de Euskadi es el nacionalismo democrático»; de ahí la importancia de conseguir en las elecciones un Parlamento Vasco «lo más nacionalista posible»33; de ahí, también, que Ardanza exclamara al finalizar la campaña que lo que necesitaba Euskadi era más nacionalismo, más PNV, porque el «otro» voto sólo servía para hacer oposición a los nacionalistas ${ }^{34}$.

La repetición de que lo que necesitaba el País Vasco era más nacionalismo, a la vez que apertura a lo universal, para poder estructurar la sociedad vasca de manera más cohesionada, integrada y fuerte ${ }^{35}$, no pued

30 Deia $15,5$.

31 Deia 19, 4.

32 Deia 16, 8. Ver, también, Correo 21, 26.

33 Deia $17,6$.

34 Correo 22, 19.

35 Ver Correo 9, 26. 
entenderse sin tener en cuenta el miedo, la agresividad y la sorpresa que provocaban, entre otros factores, la fragmentación del voto nacionalista e ideas y Partidos como Unidad Alavesa (Egibar manifestó que el PNV había detectado en Gipuzkoa intentos de crear Partidos similares al de UA en $\mathrm{Araba}^{36}$ ), que se interpretaban como factores de disgregación y de localismo. En su momento se verá la importancia que se dio a este Partido en la crítica del PNV. De momento, baste decir que Egibar manifestó al comienzo casi de la campaña: «Hace falta estructurar el país. Queremos dotarle de la posibilidad de poder decidir su propio futuro. No queremos ser ni más ni menos que nadie. Y a mí no me importa la estructura política en la que nos vayamos a ubicar, si federal o confederal... Si un país, un pueblo tiene fe en sí mismo y está organizado, llegue lo que llegue, saldrá adelante, pero tiene que ser un pueblo fuerte. Y ante tanta disgregación y localismo, lo que hace falta es un nacionalismo fuerte que vertebre este país» ${ }^{37}$.

En pura lógica con su proyecto, el nacionalismo del PNV defendió que el País Vasco (nunca se utilizó el término de nación, ni de pueblo) lo integraban todos los que trabajaban y vivían en Euskadi. Así lo defendió Ardanza en su entrevista con representantes de los centros regionales de la margen izquierda, añadiendo que «hay que aceptar que es buena la existencia de la pluralidad. Es buena para la democracia, porque ésta se basa en el respeto a las distintas ideologías... No basta sólo con que nos soportemos civilizadamente, sino que tenemos que cohesionarnos e integrarnos socialmente. Así haremos más próspero el futuro de nuestros hijos» ${ }^{38}$.

Lo mismo dijo Arzalluz al tratar de interpretar sus palabras acerca de su preferencia del negro euskaldun sobre el blanco desconocedor y despreciativo del euskera. El nacionalimso vasco no era ni racista ni xenófobo; aceptaba a todos, fuese cual fuese su origen ${ }^{39}$.

En resumen, el «nacionalismo no es un libro donde se recoge un montón de teorías. Es un sentimiento, es progreso y, sobre todo, capacidad de decidir; es autonomía» ${ }^{40}$. Euskadi —interpretaba Egibar de una manera totalmente contradictoria con lo que era esencial en el discurso nacionalista, la ausencia de vertebración y de cohesión,- - poseía un sen-

36 Deia $17,6$.

37 Deia 10, 4. Ver, también, Correo 21, 26, donde Ardanza responde así a la pregunta de si le inquietaba el mapa político adelantado por las encuestas: «Sí, sobre todo la fragmentación del voto nacionalista y el que la abstención sea también mayoritariamente nacionalista. Yo a estos últimos les diría que perfectos no somos nadie, pero que opten por el PNV, el único partido con prestigio y fuerza para liderar un nacionalismo sensato y de progreso».

38 Deia 20, 5.

39 Correo 20, 19. Ver también, Deia 16, 8.

40 Deia 11, 4. Son palabras de Egibar en el mitin de Lasarte. 
timiento diferencial, que unía a sus ciudadanos, a diferencia de lo que ocurría en España ${ }^{41}$.

De lo escrito hasta ahora cabe concluir que la campaña del PNV no fue en absoluto radical en sus contenidos nacionalistas, menos aún, si la comparamos con otras campañas. Se defendió, como era habitual en otros momentos, una estrategia de desarrollo político gradual, de ninguna manera rupturista. Y, lo que es más importante, se indicó que el camino hacia el autogobierno y la autodeterminación debería hacerse según el marco jurídico, que ofrecía el derecho constitucional vigente a través de la Constitución y el Estatuto de Autonomía de Gernika. Por todo ello extraña que al acabar la campaña se preguntara a Ardanza, dando por sentado que el PNV había radicalizado su mensaje, si ello no ocasionaría la pérdida del electorado de centro. La respuesta de Ardanza fue: «Si al final hemos conseguido el equilibrio, no ${ }^{42}$. Esto parece indicar el reconocimiento de que en algún momento, al principio, se produjo una radicalización, que sería posteriormente moderada.

Hay que constatar que tanto los comentarios de prensa como los Partidos $^{43}$ insistieron durante la campaña en tal radicalización, interpretando el fenómeno como un intento del PNV de llegar a los votantes de otros partidos nacionalistas. Sin embargo, los datos aportados por la prensa y aquí recogidos no permiten concluir semejante interpretación, a pesar de las intervenclones aisladas de Arzalluz sobre razas y lenguas, sobre el derecho de Aznar y González a participar en la campaña «porque desde su perspectiva esto es España» ${ }^{44}$ o sobre la interpretación funcional de

41 Ibidem.

42 Correo 21, 26.

43 Ver en Correo 11, 17, la interpretación de Ramón Jáuregui, según la cual el PNV habría radicalizado su discurso nacionalista insistiendo en la independencia (el articulista sólo cita el testimonio de Arzalluz al comienzo de la campaña recogido en este trabajo), porque al no ver segura la victoria electoral, pretendía sacar votos del electorado radical, «dejando a un lado, peligrosamente, a los sectores moderados». Jáuregui se felicitaba de que el PNV llevara el debate de la independencia a la campaña, ya que hasta entonces siempre lo había tratado en períodos interelectorales. Ello era positivo para los socialistas, porque «un PNV radical beneficia al PSE». Parece cierto que un PNV independentista beneficiaría al PSE, que quedaría ante el electorado moderado como el defensor de la Autonomía y del autogobierno. Tal radicalización parece que la deseaban los socialistas, pero no cayó en ella el PNV. Al tercer día de campaña era prematuro hablar en esos términos y si, por otra parte, los hechos en política tienen alguna importancia, que la tienen al completo, el fracaso electoral de los socialistas probaría a sensu contrario que la radicalidad nacionalista fue muy pequeña. También Herri Batasuna afirmó que el PNV se había acercado durante la campaña a sus posiciones nacionalistas, pero tal afirmación simplemente pretendía deslegitimar la estrategia habitual del PNV y, a la vez, apoyar la validez de sus tesis radicales (Ver Deia 15, 8).

44 Correo 16, 27. Ver también, Deia 16, 8. 
España en la frase «ipara qué nos vale España si con su política (socialista) no podemos vivir?» ${ }^{45}$, o sobre la patria, «para nosostros Euskadi sigue siendo nuestra única patria» ${ }^{46}$, que de ninguna manera alteraron el contenido del discurso nacionalista. Este no se alteró ni siquiera con la presentación, tan típicamente nacionalista, del nacionalismo vasco como esencialmente opuesto, diferente y enfrentado al nacionalismo español, que hizo también Arzalluz. Frente a la ineficacia, cultura del pelotazo, pesebrismo, radicalismo, extremismo, imperialismo y exclusivismo del nacionalismo español y de lo español, se levantaba la esencia vasca: la honradez, la eficacia, la laboriosidad (el vasco es «un hombre trabajador, nunca mísero, ni granuja, al que no le va eso del pelotazo»), la generosidad y la entrega por el país. El nacionalismo español era mucho más radical, extremo, invasor y excluyente que el vasco. «De hecho - manifestó Arzalluz- si aquí nos han salido a tiros algunos jóvenes desde hace treinta años es porque desde allí, enarbolando un nacionalismo y una bandera, pero con el fusil por delante, impusieron la ley de las armas en nombre de un nacionalismo feroz y, a veces, ridículo» ${ }^{47}$.

La irónica frase nacionalista, que destacó El Correo hacia la mitad de la campaña, «que estén tranquilos, que en cuatro años no nos vamos a separar» ${ }^{48}$, se completó con la afirmación de que no era «previsible una disgregación de España» ${ }^{49}$. Fue lo más radical en boca de un nacionalista del PNV. Arzalluz, a cuya cuenta corrió la defensa del ser nacionalista, no de la política o proyecto nacionalistas, justificó su campaña como una defensa ante las provocaciones de otros Partidos como, por ejemplo, el Partido Socialista, que con su postnacionalismo le habría obligado a hablar de nacionalismo y a no centrarse en los problemas del país. «Nos

45 Correo 16, 27.

46 El Mundo del País Vasco 16, 16.

47 Correo 17, 22. En Deia 17, 6 se amplían las consideraciones de Arzalluz sobre el nacionalismo español: «Nos dicen que dejemos de profesar que Euskadi es nuestra única patria porque hay otra patria común, y esto nos lo dicen desde un nacionalismo mucho más extremo que el nuestro. El nacionalismo español es mucho más radical que el nacionalismo vasco». Otra muestra del nacionalismo español la vio Arzalluz, «cuando se (armó) la de Dios es Cristo con la "eñe" a cuenta de que es la letra española». «...son mucho más invasoramente y excluyentemente nacionalistas que nosotros, que nos desacreditan y se ríen cuando hablamos de derechos históricos, y salen ellos con el derecho histórico para reivindicar Gibraltar o dicen que la unidad de España, históricamente, es intocable. La historia vale para lo que a ellos les vale y no vale para lo que a nosotros nos vale. La historia es una realidad para todo, para Gibraltar y para los derechos vascos». Arzalluz llegó a decir que cuando el tenista Alberto Berasategui perdía los partidos, «dicen que es el tenista vasco y, cuando gana, es el tenista español».

48 Correo 16, 27.

49 Deia 22, 5. Afirmación hecha por Arzalluz al final de la campaña. 
han forzado - dijo - a acotar el campo con sus provocaciones. Nosotros somos nacionalistas ${ }^{50}$. Con otras palabras y en otro contexto Atutxa vino a concluir lo mismo, al decir: «Este país ha sido atracado por propios y extraños, en lo económico, en lo industrial, en cuanto a la cultura y nuestra lengua, pero no ha conseguido absolutamente nadie atracar y llevarse el sentimiento abertzale de respeto y de solidaridad de esta sociedad» ${ }^{51}$.

\section{Cuestiones programáticas}

El problema de la violencia en el País Vasco y, muy especialmente, el tratamiento de tal problema a través de posibles conversaciones, de la reinserción y de la aplicación general del Pacto de Ajuria Enea llenó la parte más importante de la imagen del Partido Nacionalista Vasco, alrededor del $22 \%$. La pacificación, dicho con otras palabras, fue la mayor preocupación, cuantitativamente hablando, expresada en la campaña por este Partido y sirvió en buena medida para crear una imagen negativa de otros Partidos Políticos.

El Pacto de Ajuria Enea, se defendió, no pretendía marginar a nadie, sino atraer a la democracia al mundo radical vasco. Su vigencia era plena, mientras no fuese sustituido por un consenso superior. Cualquier cambio de estrategia en este sentido debería contar con el visto bueno de la Mesa de Ajuria Enea ${ }^{52}$. El Pacto requería una profunda reflexión, que podía llevar, incluso, a trasladar la Mesa de Ajuria Enea al Parlamento Vasco. Pero, en principio, el PNV se mostró contrario a semejante traslado, argumentando que los acuerdos sobre temas tan delicados como la gestación de la paz exigían formas discretas y, por ello, ajenas a los foros públicos ${ }^{53}$. El traslado podía acabar con determinados consensos y lo importante era lograr el objetivo de la pacificación. Si bien se estaba dispuesto a establecer nuevos consensos sobre la cuestión, se rechazaba de plano soportar indefinidamente lastres o rémoras que la obstaculizasen.

Uno de los problemas que se añadía al proceso hacia la paz era el de su politización, que nacía precisamente del carácter ya irreversible del mismo. Así como la reinserción había encontrado oposición en el Partido Popular durante el último verano, así se esperaba ahora que el punto 10 del Pacto, en el que se preveía un final dialogado a la violencia, previa renuncia de ETA a las armas, encontrase semejante rechazo.

\footnotetext{
50 Deia 22, 5.

51 Deia 10, 5.

52 Ver Correo 8, 15; Deia 8, 1. Ver también, Egin 8, 13.

53 Correo 11, 22; Deia 11, 5.
} 
Atutxa, siempre defensor de la reinserción, no rechazó el diálogo con alguno de los dirigentes de ETA confinados en Santo Domingo, si así lo decidía el Pacto de Ajuria Enea, pero advirtió que «la paz está en quienes disparan, extorsionan y ponen bombas» ${ }^{54}$.

El objetivo último era lograr una sociedad reconciliada, donde se alcanzara el perdón para todos. «Tenemos que resolver el problema de la violencia - declaró Ardanza en una entrevista- mediante una actitud de distensión, de diálogo, de reconciliación, de manera que no queden secuelas ni de derrotas ni de fracaso ${ }^{55}$. La negociación era una de las posibilidades $^{56}$. Se trataba, dijo en otra ocasión Juan María Atutxa, de «desterrar la violencia, pero no queremos desterrar ni marginar a los violentos. Los necesitamos. Pero recuperados... Recuperemos a todas las personas, porque todas son necesarias. Pero quienes apoyan esa vertiente (refiriéndose a HB) que lo tengan en cuenta. Que sepan que por mucho que pretendan insultarnos con esas pretendidas descalificaciones no lo van a conseguir. No me van a callar. Creo que esta sociedad necesita que algunos caminemos adelante para que toda esta sociedad consiga la tan deseada pacificación». Y respondiendo a las acusaciones e insultos de HB, Atutxa afirmó: «Siento un gran honor por poder dirigir los destinos y el camino a seguir de esta policía vasca nacida a reivindicación de esta sociedad y a su servicio» ${ }^{57}$.

A semejanza del concepto de autodeterminación, Atutxa defendió un concepto permanente de la negociación en clara distinción de lo que sería una acción inmediata de efectos definitivos. En este sentido manifestó que en «este país se habla a diario de la negociación, pero algunos se olvidan de que se negocia permanentemente ${ }^{58}$.

En los últimos días de campaña fue Ardanza, quien más manifestaciones realizó sobre la pacificación. «Soy partidario — dijo- de conversaciones con ETA. Para empezar, discretas; y, a poder ser, secretas, porque es la única forma de que realmente se pueda estar trabajando con cierta seriedad y no sometidos a la presión del día a día». El diálogo sólo podía partir de la renuncia a las armas de ETA. «Todo depende de ellos, de la voluntad que tengan. Si efectivamente ETA manifestara de

54 Correo 13, 17. Ver también, Deia 13, 17.

55 Deia $16,4$.

56 Deia $9,6$.

57 Deia 15, 5. Semejantes declaraciones aparecen en Deia 16, 11. Las mismas tesis con las mismas expresiones defendió Atutxa en el mitin, que cerró la campaña (Deia 22, 4). Arzalluz en El Mundo del País Vasco 8, 9 dice: «Los chicos de la droga, del petardo, del gaztetxe, del cohete que rompe escaparates son un problema para la sociedad y son personas que hay que recuperar, porque ellos también son vascos».

58 Deia $16,11$. 
forma clara su voluntad de dejar las armas, sería el momento de hablar. Estaríamos en lo que prevé el punto décimo del Pacto de Ajuria Enea... Mi posición sobre la violencia está muy clara y la he repetido hasta la saciedad: los puntos 8, 9 y 10 del Pacto de Ajuria Enea siguen siendo de rabiosa actualidad». La defensa de los contenidos de tales puntos no podía dar lugar a ningún tipo de escandalera, tal como estaba ocurriendo según su interpretación ${ }^{59}$. $\mathrm{Si}$, precisamente, argumentaba Ardanza, había sido posible en 1988 tener contactos con ETA y en 1989 conversaciones oficiales, fue porque «todos los demócratas teníamos asumido el punto 10 del Pacto de Ajuria Enea: que la solución final al problema pasa por una mesa de diálogo. Sólo pido coherencia. Cuando se forme el nuevo Gobierno, volveré a reunir a la Mesa y preguntaré si todos reasumen lo que se firmó. Si lo logramos, bien. Y si no, aunque todos lo justificarán muy bien, alguno tendrá que decir que no le conviene mantener el espíritu de 1988 y dónde ve la mejor opción. Romper es muy fácil, pero espero que la gente tenga la suficiente prudencia como para antes de dar por superada una etapa tener la siguiente prevista y bien amarrada» ${ }^{60}$.

Detrás de toda la política propuesta para realizar la pacificación estaba la convicción de que «ETA no es una banda de delincuentes y (de que la violencia) sólo se resolverá por vías políticas» ${ }^{61}$. La afirmación concordaba con lo dicho sobre los presos de ETA: «El problema de los presos es un problema político y requiere vías políticas de solución, no policiales como pretenden en Madrid ${ }^{62}$.

Preguntado Ardanza en una entrevista sobre si en la próxima legislatura se acabaría con la violencia, respondió: «Este es un tema en el que uno ya no sabe si confunde deseos con realidad. Hay una voz interior que me dice que sí, pero no sé si esa voz me está engañando. No lo sé» ${ }^{63}$.

La defensa del sistema político se concretó, en un principio, en los Partidos políticos y en la clase política. «La mayoría - manifestó Ardan$\mathrm{za}-$ somos gente volcada en un compromiso de servicio al país»64. Lógicamente, la mayor defensa se hizo del PNV y de sus candidatos ${ }^{65}$, pero se manifestó públicamente el desprestigio, en el que había caído la clase política. Lo hizo Atutxa al manifestar que «la poca credibilidad que pudo

Correo 19, 21; Deia 19,5.

60 Correo 21, 26.

${ }^{61}$ Correo 10, 15. La afirmación aparece de forma destacada y entrecomillada sin atribución a persona alguna.

62 Deia $10,4$.

63 Deia $16,4$.

${ }_{64}$ Correo 8, 20. Deia 8, 5. Ver también, El Mundo del País Vasco 8, 9.

65 Ver Deia 17, 5. Ver también, Correo 21, 26. 
tener el mundo político hace unos cuantos años en estos momentos está por los suelos. Estamos todos en el mismo saco. Nadie cree en los políticos y somos nosotros quienes debemos recuperar nuestra credibilidad. Tenemos que demostrar que no somos todos del mismo talante, que nuestro proyecto no es igual» ${ }^{66}$. Más tarde la defensa del sistema político se extendió a la lucha contra la abstención ${ }^{67}$ y a la defensa del voto reflexivo ${ }^{68}$, pensadas para dirigir el voto hacia el PNV, pero, especialmente, para garantizar la vigencia del régimen político. La llamada al ejercicio democrático del voto se apoyó en el argumento de la necesidad de defender y garantizar la democracia ${ }^{69}$. En este sentido es claro el testimonio de Arregi: «Animad en vuestro entorno y dadles ánimos para que la gente vote. Aunque es peligroso, porque se pueden ir a otros partidos, más peligroso es para una democracia que la gente no haga uso de este derecho» ${ }^{70}$. La misma preocupación y el mismo criterio manifestó Ardanza ante el anuncio de las encuestas de un $40 \%$ de abstención: «Comprendo que los ciudadanos puedan tener razones de uno $\mathrm{u}$ otro tipo, pero una democracia supone participación» ${ }^{71}$. En la defensa del sistema democrático no faltó alguna atención al problema de la corrupción, sobre el que Ardanza insinuó un negativo papel de la prensa diaria y defendió que en Euskadi existía un comportamiento más honesto y transparente que en Madrid. Como el caso de las «tragaperras» seguía coleando, Ardanza afirmó que «todos debemos acercarnos a este problema desde la lealtad y seriedad, porque la política necesita recuperar prestigio» ${ }^{72}$. Arzalluz declaró que al PNV no le gustaba hurgar en heridas como las de la corrupción ${ }^{73}$.

En esta línea de recuperación del prestigio perdido puede situarse la interpretación de que en la campaña se había «demostrado una mayor madurez política y una menor crispación» ${ }^{74}$, aunque ya se encargó Egibar de dar otra explicación al afirmar que la normalidad de la campaña se había debido a la certeza que tenían todos los contendientes de que el ganador iba a ser Ardanza ${ }^{75}$.

66 Deia $17,5$.

67 Ver Correo 11, 17; Deia 11,4.

68 Ver Correo 14, 19; Deia 14, 5. En Deia 16, 5 Ardanza declara que «la mejor carta de presentación que podemos hacer para que nos voten es decir: Ya nos conocéis».

69 Ver Correo 21, 19; Deia 21, 1 y 4.

70 Deia $11,4$.

71 Deia $21,4$.

72 Correo 21, 27. Acusaciones contra la prensa por actuar en contra del PNV o, simplemente, de dirigentes del PNV aparecen en Deia 21, 4; Deia 22, 4 y 5; Correo 22, 19, donde se recoge la acusación de Arzalluz contra El Correo de «hablar del PNV con pasión y a la contra».

73 Deia 21, 4.

74 Correo 21, 19. Ver Deia 21, 4.

75 Deia 22, 5. 
La defensa del Estado de Bienestar llevó a Ardanza a rechazar el liberalismo económico a ultranza y a defender el principio de que una de las tareas fundamentales de todo Gobierno era la redistribución de la riqueza. La política del PNV se había movido en tal línea, como lo demostraban en su opinión la Ley de Servicios Sociales, la universalización de la sanidad y el salario social, a pesar de las reticencias de los compañeros de Gobierno, los socialistas. El desarrollo económico siempre había tenido un carácter instrumental al servicio de fines sociales, ya que una sociedad basada exclusivamente en criterios de competitividad podía producir entre sus miembros efectos de exclusión y marginación. En el futuro el compromiso nacionalista apostaba por mantener el Estado de Bienestar garantizando las pensiones, la sanidad universal, la educación, la lucha contra las desigualdades y la marginación, la protección de los consumidores y los servicios sociales a través de reformas, que distribuyesen las cargas entre la Administración y la sociedad civil, en la que debía desarrollarse una mentalidad de ahorro y previsión. La crisis económica y el envejecimiento de la población presionaban sobre el Estado de Bienestar y se imponía una mejora de la gestión de los recursos disponibles y un desarrollo de la solidaridad ${ }^{76}$.

La insistencia en la política favorable a evitar o reducir, al menos, las desigualdades y a seguir construyendo el bienestar para todos no escapaba a la necesidad de defenderse de los ataques de otros Partidos Políticos, que acusaban al PNV, como era habitual, de ser un partido netamente burgués 77 . De ahí que los nacionalistas presentasen la lucha contra las desigualdades como un logro, como un éxito de su política durante los últimos años, al que había que añadir un crecimiento económico mayor que el que experimentaba el resto de España y el desarrollo de las infraestructuras $^{78}$.

Entre los éxitos del Partido se encontraban, también, la superación de la ruptura interna del propio Partido, la solución al enfrentamiento interinstitucional entre Gobierno Vasco y Diputaciones, el desbloqueo del Parlamento, la superación de la crispación social y el logro de la unidad

76 Correo 12, 20; Deia 12, 5, donde puede leerse la intervención de Azcuna en defensa del Estado de Bienestar en materia de sanidad y las correspondientes correcciones, que debían hacerse para ahorrar medios y dinero. Ver, también, en defensa del Estado de Bienestar, Correo 10, 15.

77 Ver Deia 9, 6.

78 Correo 14, 19. Ver en Correo 18, 23 palabras de aliento y esperanza en el futuro para los empresarios; así mismo, Deia 16, 11 y 18, 5. En las declaraciones a Deia 16, 4 Ardanza da una visión muy positiva y optimista de los cambios, que distinguían la Euskadi de 1994 de la Euskadi de 1984. 
en torno a la lucha contra la violencia, males todos ellos que caracterizaban a la sociedad vasca de 198479 .

Hubo un reconocimiento de que la política de inversiones seguida por los Gobiernos nacionalistas durante los últimos catorce años para mantener la industria no había sido la adecuada, aunque se matizó que no se podía «dejar que todo se hundiera a la vez»80.

Poco más que destacar en este apartado. Sólo hay que citar la inspiración cristiana y humanista del Partido Nacionalista, la defensa del desarrollo tecnológico y de la formación y la lucha contra el paro ${ }^{81}$.

\section{Cuestiones de Gobierno}

Antes de que se hubiese cumplido la mitad de la campaña, Ardanza ya había manifestado que la anterior coalición de gobierno entre PNV y PSE-EE había sido indudablemente positiva. Incluso la sociedad, pasadas las primeras tensiones, la había interpretado de manera bastante favorable, según sus palabras. Los recientes enfrentamientos y acusaciones entre socialistas y nacionalistas, que expresaban un cierto distanciamiento entre ambos, no eran más que parte de una «estrategia preelectoral», de la que nadie debía extrañarse ${ }^{82}$. En este sentido, se dijo que el Presidente González había enmendado el anuncio de los socialistas sobre su disposición a convertirse en oposición en la siguiente Legislatura al decir que los resultados del anterior Gobierno de coalición habían sido excelentes y que había que pensar en la misma dirección ${ }^{83}$.

Tales manifestaciones preparaban el reconocimiento nacionalista de que sería prácticamente imposible un gobierno monocolor del PNV y que se impondrían necesariamente pactos de Gobierno o de legislatura. Excluido como socio de Gobierno Herri Batasuna, prácticamente se excluía también, por muy arriesgado, un gobierno nacionalista con EA, ya que, a tenor de las encuestas, no pasaría de un apoyo parlamentario de 30 diputados. Así mismo, se rechazaba un Gobierno provisional hasta las elecciones municipales, que sería definitivo a partir de las mismas, y un Gobierno en minoría del PNV apoyado en la sombra por el Partido Popular ${ }^{84}$. El gobierno unipartidista sólo sería posible en el supuesto de un gran crecimiento nacionalista, que no anunciaban los sondeos, o en el supuesto de

\footnotetext{
79 Entrevista a Ardanza en Deia 16, 4.

80 Deia $9,6$.

81 Ver Deia 9, 6; Deia 10, 4; Deia 16, 11.

82 Correo 11, 22; Deia 11, 5.

83 Ver Correo 21, 26.

84 Deia 21, 4.
} 
que estuviesen ausentes del Parlamento varias fuerzas políticas, lo que tampoco se esperaba, ya que la segura presencia de Izquierda Unida obligaría a entrar en el juego parlamentario a Herri Batasuna. Fue Egibar, quien afirmó: «Ni en la vida ni en la política se pueden confundir los deseos con la realidades y no creo que vayamos a estar en condiciones de poder gobernar en monocolor tras el 23 de octubre. Harán falta pactos de Gobierno o de legislatura». Los pactos deberían ser «multidireccionales», si se confirmara la presencia de todos los grupos en el Parlamento ${ }^{85}$.

Un gobierno en solitario no era del gusto de Ardanza, porque se vería obligado a funcionar «al albur de lo que se le (pudiese) ocurrir a un partido en el Parlamento». El futuro Gobierno debería contar con apoyos suficientes para ser un gobierno fuerte ${ }^{86}$. Por otra parte, el futuro socio de Gobierno debería ser tal que permitiese la gobernabilidad y la cohesión en los tres Territorios Históricos ${ }^{87}$. Este no parecía ser otro que el Partido Socialista. Así lo dijo expresamente Arzalluz: «Ardanza va a seguir gobernando y, muy posiblemente, con los socialistas, aunque ahora estén diciendo que igual se quedan en la oposición. Ya veremos. Y si ellos no quieren tendremos que gobernar con el que sea ${ }^{88}$. De todos modos, no se excluía a otros Partidos para compartir Gobierno con ellos. La elección, por ejemplo, entre PSE y Partido Popular no sólo dependería de los resultados, sino, muy especialmente, del programa. Ya Egibar había dicho que no era imprescindible la presencia del PSE-EE en el Gobierno, razonando que desde la firma del Pacto de Ajuria Enea no había habido ningún acuerdo importante con los socialistas ${ }^{89}$. En el supuesto de pactar con los socialistas, y ante la pregunta de si el PNV exigiría «dote» en forma de transferencias, Ardanza respondió: «Ya veremos cómo se lleva la negociación, porque con los socialistas tenemos una doble corriente de relación. Con el PSE prácticamente no la hay, pero con el PSOE en su conjunto hay una relación permanente. Probablemente si se plantea una negociación a fondo con el PSE funcionen también en paralelo ambas

85 Correo 12, 20.

86 Correo 18, 23; Deia 18, 5. Aunque Arregi había manifestado que «un gobierno de coalición siempre es más débil. Por lo tanto, necesitamos un gobierno fuerte, un gobierno nacionalista y la única vía es apoyando al PNV» (Deia 11, 4), no puede verse en tales manifestaciones una contradicción con lo dicho por los demás políticos. No sólo hay una diferencia entre el deseo y la realidad, sino que la presentación de la coalición como una necesidad es utilizada para recabar más votos y así dar menos peso a la necesaria coalición.

87 Correo 19, 21; Deia 19, 5.

88 Correo 20, 19; Deia 20, 4. Ante la dificultad, según Arzalluz, de pactar con grupos nacionalistas, porque carecían de «cupo», ya había declarado que «hasta ahora nos hemos entendido con otros (los socialistas) y en el futuro nos seguiremos entendiendo» (Correo 16, 27).

89 Deia $11,4$. 
vías: la de las mesas oficiales formales y las paralelas... No sé por qué se considera dote al cumplimiento de una ley como el Estatuto. Creo que lo que habría que hacer es completarlo cuanto antes para que nadie interprete que estamos en un mercado persa» ${ }^{90}$.

No obstante todo lo dicho, el único voto que permitía hacer una política nacionalista era el voto al PNV; cualquier otra orientación de voto era antinacionalista. Esto quería decir que todo pacto de Gobierno o de Legislatura era una disminución en la capacidad de acción nacionalista. Con toda claridad lo dijo Ardanza al final de la campaña: «Vamos a ganar, pero queremos ganar con holgura, porque Euskadi necesita un Gobierno fuerte, más nacionalismo, más PNV, para dar un empujón a la renovación de este país. Y ahí hay un voto que sirve para gobernar en nacionalista, el nuestro, y otro que sólo vale para hacer oposición a los nacionalistas»91. Por ello el ideal, el desideratum imposible era la obtención de una mayoría absoluta, que permitiese al PNV gobernar en solitario - ya había dicho Arzalluz de la anterior Legislatura que «gobernamos juntos por responsabilidad y no por gusto»- sin tener que verse en la obligación de pactar con los socialistas ${ }^{92}$, que, por otra parte, habían manifestado su opinión de un posible paso a la oposición. Por ello, las últimas palabras sobre el tema las dijo con el mismo tono superfluamente agresivo Arzalluz: «Nosotros tendremos que gobernar y lo haremos con otros, y si nadie quiere gobernaremos solos. Y si no podemos, convocaremos nuevas elecciones y diremos al pueblo que no hay manera de gobernar aquí» ${ }^{93}$.

La recuperación de la hegemonía se consideraba que estaba todavía lejos, pero de momento bastaba con que el electorado no viese riesgos en una mayoría nacionalista del PNV94. No sólo no había riesgos en el voto al PNV, sino que era éste el indicado para, además de realizar los fines ya señalados, desbloquear situaciones políticas como la de Guipúzcoa, que estaban retrasando la construcción nacional vasca ${ }^{95}$. En palabras de Ardanza, «la única opción nacionalista democrática útil es la del PNV»96.

90 Correo 21, 27. Ver, también, sobre la cuestión de Gobierno: Correo 22, 19; Deia 22, 4. En Correo 22, 19 Ardanza, haciendo un balance de la campaña, manifestó que en materia de coalición de Gobierno actuaría sin apriorismos, buscando la máxima coincidencia programática, no ideológica, y una mayoría integradora y cohesionadora del país, aunque esperaba que el PSE-EE superase su tentación de «echarse al monte y pasar a la oposición», adoptando una actitud abierta ante futuros pactos.

91 Correo 22, 19. Ver Deia 22, 4.

92 Ver Deia 11, 4.

93 Deia 22, 4.

94 Ver Correo 21, 26.

95 Ver Correo 11, 17; 14, 19; Deia 11, 4; 14, 5.

96 Correo 21, 26. 
Las relaciones entre Presidente de Gobierno y Partido fueron veladamente aludidas con varias intervenciones dirigidas a destacar la autonomía del Gobierno con respecto al Partido y la compenetración y respeto mutuo entre Ardanza y Arzalluz ${ }^{97}$.

\section{B) La crítica de los Partidos Políticos}

Una tercera parte de las intervenciones críticas con los Partidos recayó sobre el Partido Socialista de Euskadi-Euskadiko Eskerra, lo que representó un $14,73 \%$ del total de la campaña. A excepción de ciertas palabras positivas dirigidas hacia la persona de Felipe González, «caballero» que «vino a apoyar a los suyos y no habló mal de nadie»98, y a excepción del reconocimiento de la positiva colaboración socialista en la anterior Legislatura, colaboración que se esperaba para la siguiente, el resto fue un repetido, aburrido y permanente discurso desacreditador de los socialistas, que llegó hasta el extremo de las palabras de Arzalluz dirigidas contra Guerra: «Nosotros calentamos el micrófono, pero no lo ensuciamos»99.

La parte central la ocupó el recurso al ya tradicional argumento electoral de la oposición entre Madrid y Euskadi y, por consecuencia, entre los políticos de Madrid, estatalistas y de allí, y los de Euskadi, vascos y de aquí, y los problemas, intereses y preocupaciones que separaban a unos y a otros, que principalmente se usaba contra los socialistas en el poder, pero que se decía también contra todos los partidos de ámbito nacional y, más aún, contra una supuesta esencia española, España, lo español o el nacionalismo español. Arzalluz entró, desde un principio, por esta vía al decir: "Anguita ya está aquí. Aznar parece que va a sentar sus reales en Euskadi y González y Guerra, aunque se pegan, van a venir juntos. Estos paracaidistas debatirán lo de Madrid y no lo vasco, porque quieren hacer de estas elecciones una especie de muestra de lo que suben unos y bajan otros. Y no estamos dispuestos a que nos utilicen como conejitos de India. Algunos están aquí para promocionarse y tienen Madrid como su estación definitiva. Nosotros sólo conocemos las de Eusko Trenbideak» 100 .

97 Ver Correo 20, 19; 21, 26; Deia 20, 4.

98 Correo 20, 19. La intervención completa de Arzalluz fue: «Vino a apoyar a los suyos y no habló mal de nadie. No como su señora, que creo ha estado mal asesorada». A Arzalluz se deben también las palabras de que «el "caso Osakidetza" no lo hemos tocado por delicadeza, no porque haya pacto con el PSE» (Correo 19, 21. Ver también Deia 21, 4).

99 Deia 10, 4. Estas palabras respondían a otras de Guerra en las que éste habría dicho que Arzalluz calentó el micrófono con su intervención en el Alderdi Eguna último.

100 Deia 8, 5 . E1 argumento se repitió; ver, además de otros lugares citados, Correo 16, 27; 17, 22; Deia 17, 6 . 
Si Arzalluz había calificado de «paracaidistas» a los políticos no vascos, Atutxa los llamó «carteristas» que habían «comenzado a llegar de Madrid para atracarnos en lo económico, en lo industrial y en nuestros propios sentimientos. Así que ¡ojo! y que cada uno guarde su cartera». La diferencia entre «ellos» y «nosotros» estaba según Atutxa en la pretensión nacionalista de traer de Madrid para Euskadi lo más posible, mientras que «ellos» intentaban llevarse de Euskadi lo más posible ${ }^{101}$.

De nuevo Arzalluz arremetió contra socialistas y populares en el mitin de Anoeta usando semejantes metáforas a las utilizadas el primer día. «No os engañéis - dijo-; ellos vienen y se van, mientras nuestra estación término está aquí. Además siempre nos dejarán de lado, porque unos (los socialistas) tienen su saco de votos en Andalucía y Extremadura, y los otros (el PP) en Castilla y Madrid»102.

La imagen negativa de los socialistas se creaba también con las acusaciones de pesebrismo, practicado en las empresas del INI, de cultura del pelotazo, protagonizado por personas socialistas, y de robo de las elecciones vascas, ya que socialistas y populares trasladaban a la campaña los problemas y las disputas que mantenían en las instituciones centrales del Estado, en lugar de venir a Euskadi a hablar de política industrial y económica, olvidando que se trataba de elegir al «Parlamento de la nación vasca» ${ }^{103}$. Arregi acusó al poder central de extender la opinión de que un Gobierno mayoritario del PNV sería altamente peligroso ${ }^{104}$.

A todo esto se añadían la incoherencia, la desorientación, la pretensión de resolver el problema de la violencia por medios policiales ${ }^{105}$, la alteración permanente de los objetivos políticos — «dentro de poco, dijo Ardanza, defenderán el carlismo y los pactos con la Corona»- y la pre-

101 Correo 10, 15. Ver Deia 10, 4. Atutxa manifestó en el mitin, como comunicación de su servicio de información, que «caminando por nuestras calles vascas hay una verdadera avalancha de carteristas venidos estos días desde Madrid; va a haber más en los próximos días, y a pesar de estar controlados, lo hacen de forma tan sibilina que no tenemos pruebas para deternerlos, por lo que advertimos a la sociedad del peligro que corre estos días» (Deia 10, 5). Unos días más tarde Atutxa rectificó lo de «carteristas», diciendo que había sido una broma, con la que no había pretendido insultar a nadie, broma que, de hecho, había servido para comprobar que la sociedad no estaba preparada para aguantarla (Correo 13, 17).

102 Correo 10, 15. Ver en Deia 10, 4 los reproches de Egibar acerca de los cambios de criterio de Mario Onaindía sobre la pacificación.

103 Correo 17, 22; Deia 17, 6. En Correo 14, 19 se lee: «Que expliquen —son palabras de Arzalluz - por qué ha vuelto a retrasar Borrell el fin del monopolio de Telefónica. ¿Tienen miedo a que se les acaben las colocaciones? Eso que yo suelo llamar la mafia del INI. ¿Están defendiendo el "pesebrismo"». En Correo 20, 19 aparece la afirmación de que «el INI no es más que un gigante corrompido que esteriliza todo lo que toca».

104 Ver Deia 17, 6.

105 Deia 10, 4. 
tensión de mantener bajo su control zonas como la margen izquierda, a diferencia del PNV, que pretendería superar guetos y aislamientos creando una Euskadi integrada106.

La acusación más grave fue la de falsedad dirigida contra círculos políticos y periodísticos de Madrid, sin más especificación, que supuestamente hablaron de pactos o acuerdos secretos entre PNV y ETA para declarar una tregua, falsedad, que llevó a Arzalluz a declarar: «Qué es lo que más les preocupa, que el PNV llegue a un acuerdo con ETA o que ETA deje de matar. Esto es algo que yo quiero conocer, porque cada vez tengo más claro que hay mucha gente que no quiere que ETA termine»107.

Otra parte importante de la imagen negativa de los socialistas se elaboró denunciando la pésima política del Gobierno socialista con Euskadi. Esta incluía las acusaciones de que el INI había impedido que el Gobierno Vasco gestionara los sectores claves del país, sugiriendo, además, que el cierre de grandes empresas en el País Vasco se había debido a tal causa, y de que el Gobierno de Madrid entorpecía - según Arzalluz- el desarrollo económico de Euskadi al haber «metido el fantasma de ETA al capital extranjero y las multinacionales, a pesar de que ETA nunca había atentado contra ellos»108. Buena parte de los males, que aquejaban a la industria vasca, se debía según Arzalluz, a la absurda política económica del Gobierno socialista ${ }^{109}$. «Nosotros — dijo- no hemos dejado de ser industriales por churro, porque tres años más con la política de Solchaga y aquí no queda una sola fábrica» ${ }^{110}$. Por otra parte, se censuró la actitud del Gobierno ante el colectivo de presos de ETA, insistiendo en que «el problema de los presos es un problema político y requiere unas políticas de solución, no policiales como pretenden en Madrid» ${ }^{111}$. Así mismo, se pidió a los seguidores del PNV sensibilidad ante las torturas y violación de los derechos humanos cometidos con los presos. «No seamos insensibles ante esto. Porque ahí radica la piedra angular de nuestro partido, un partido humanista, de inspiración cristiana, donde los derechos humanos están en el frontispicio de nuestra actuación. De lo contrario, la destrucción moral está servida» 112 .

Si bien el temor del Gobierno socialista a que el traspaso de más competencias aumentase la soberanía y el poder de Euskadi explicaba, según

\footnotetext{
106 Correo 20, 19; Deia 20, 4.

107 Deia 22, 1 y 4 y Correo 22, 19.

108 Deia 9, 6. Los mismos contenidos aparecen en Correo 10, 15.

109 Correo 17, 22.

110 Deia 10, 4.

111 Deia 10, 4.

112 Deia 10, 4.
} 
Egibar, que no se cediesen materias de ámbito financiero, laboral o económico, también la carencia de un proyecto autonómico definido era causante de lo mismo. Ahí estaba el artículo 150.2 de la Constitución, que no se desarrollaba ${ }^{113}$. La paralización de la transferencia de la Seguridad Social y otras materias suponía, según Ardanza, la comisión de un fraude de ley ${ }^{114}$.

La acusación más grave la hizo Ardanza, cuando, con motivo de la campaña de Unidad Alavesa contra los nacionalistas, reprochó tanto a socialistas como a populares su «silencio cobarde y vergonzoso». Ardanza añadió: «Tienen miedo de que si levantan la voz como yo, les llamen traidores y les arrebaten cuatro votos. Se callan por eso y porque en el fondo les trae sin cuidado que aquí se fomente el odio. Mejor que mejor, porque así se debilita más Euskadi»115.

La crítica antisocialista se completó con la descalificación de los socialistas vascos, empezando por su candidato a Lehendakari, Jáuregui, objeto tanto de comentarios poco favorables para su cultura democrática y sus estrategias políticas como de conmiseración por su precaria situación política ${ }^{116}$. La falta de autonomía y de independencia del PSE-EE con respecto al PSOE, que impedía tener interlocutores válidos entre los socialistas vascos y que llevaría, en el supuesto de una victoria socialista, a gobernar por fax, en palabras de Arzalluz, fue repetidamente manifestado durante la campaña ${ }^{117}$. Ambos elementos se recogen en la siguiente intervención de Arzalluz: «Señor Jáuregui, usted políticamente no es de aquí. Si llegara a Lehendakari gobernaría por fax, sería un segundo delegado del Gobierno en Euskadi. Y si Felipe González o Narcís Serra le dijeran "a" usted, quisiera o no, tendría que decir "a", porque son sus superiores jerárquicos. Por eso pinta menos que nosotros en Madrid. Y por eso van para abajo y seguirán para abajo»118.

113 Ver Deia 11, 4. Sobre el artículo 150.2 y la Constitución, Egibar hizo el siguiente disparatado comentario: «¿Por qué esta comunidad no tiene la posibilidad de convocar un referéndum? ¿Por qué se sacraliza tanto la Constitución si es una ley, idéntica (sic) al Estatuto?» (Deia 11, 4).

114 Correo 12, 20; Deia 12,5.

115 Correo 16, 27. Ver Deia 16, 8.

116 Ver Correo 8, 20; Deia 8, 5. En Correo 21, 26, Ardanza declara que «lo que pasa con Jáuregui es que le estamos viendo dar demasiados tumbos en poco tiempo. En las generales tuvieron un éxito tremendo aquí, eso les hizo confundirse, lanzaron lo del postnacionalismo y empezaron a comportarse como un partido de oposición. Pasado el tiempo, cambiaron aquel discurso por el de autonomismo. Como parece que tampoco les iba bien, han empezado a decir que están dispuestos a pasarse a la oposición. Luego traen a Felipe González para que les eche una mano en la campaña y les enmienda la plana diciendo que los resultados del Gobierno de coalición han sido excelentes y que hay que seguir pensando en la misma línea».

117 Ver Deia 11, 4; 22, 4; Correo 17, 22.

118 Correo 14, 19. Ver Deia 14, 5. 
Había, de todos modos, otras razones que explicaban el descenso de los socialistas en Euskadi. «Más bien — dijo Ardanza- me da la impresión de que los socialisas están agotando el ciclo histórico de su responsabilidad de gobierno a nivel estatal y que eso les está afectando también aquí. Luego está lo de la operación de EE, que ha sido un camelo impresionante. Parece que los líderes de EE no conocían a su electorado, porque al final ni se han ido con el PSE, ni con EUE»119.

El segundo Partido más censurado fue Unidad Alavesa con un $23,74 \%$ de la parte dirigida a los Partidos Políticos, que representaba un 10,57\% del total de campaña.

Esto supuso que el PNV le dedicara mayor atención cuantitativa que al mismo Partido Popular, si bien hay que indicar que el número de ocasiones en las que se refirió a él fue más reducido.

La importancia concedida a Unidad Alavesa iba más allá de la lucha meramente electoral. Se veía en ella no sólo a un adversario electoral, sino a quien ponía en cuestión el mismo mapa político diseñado por el Estatuto de Gernika y los contenidos que el nacionalismo consideraba vitales para la reconstrucción nacional vasca, como podía ser el euskera. Unidad Alavesa no sólo anunciaba una política antinacionalista, sino que manifestaba de forma evidente la inexistencia de una sociedad vasca vertebrada y cohesionada sobre valores y proyectos comunes. Por éste y otros fenómenos semejantes el PNV insistía tanto en la necesidad de conseguir la unidad y cohesión sociales.

Como uno de los argumentos utilizados por UA era la marginación sufrida por Alava en beneficio de los demás Territorios Históricos, o lo que es lo mismo, que el nacionalismo no era rentable, el PNV actuó destacando que no había ciudad «mejor dotada, con mejor calidad de vida» ni en la Comunidad Autónoma, ni en el Estado ni en Europa ${ }^{120}$. No sólo lo dijo en sus mítines, sino que publicó un breve folleto con el título de «UA miente a los alaveses. ¡Compruébalo! Estos son los datos verdaderos», en el que se afirmaba que Alava era el territorio más beneficiado económica y socialmente por el Gobierno Vasco. Según este folleto Alava recibía del Gobierno Vasco 25.000 millones más de los que aportaba; Vitoria contaba con un nivel de servicios excepcional; Alava tenía el doble de camas hospitalarias que el resto; la capitalidad suponía la creación de 2.500 empleos indirectos y las ayudas del Gobierno a grandes proyec-

119 Correo 21, 27. Como «afrenta institucional» calificó Antton Aurre, Presidente de las Juntas Generales de Bizkaia, la celebración por los socialistas vascos de un acto electoral ante el árbol de Gernika (Deia 18, 4).

120 Correo 11, 22. Ver Deia 11, 5. 
tos empresariales alcanzaba el 52\% del total. Mosquera era censurado por insultar al funcionariado vasco y por ocultar que él también lo era, «disfrutando de uno de los niveles retributivos más elevados de la Administración vasca» y militando en ELA, pese a ser antinacionalista ${ }^{121}$.

Los datos recogidos por el folleto fueron confirmados y desarrollados en una intervención del Consejero en funciones de Economía y Hacienda, José Luis Larrea, que permitían concluir que era «indudable que la pertenencia de Araba a Euskadi le reportaba innumerables beneficios económicos», cuya prueba estaba en en el nulo endeudamiento de la Diputación Foral de Araba. «Si Araba — añadió Larrea- fuese como Nafarroa... y si tuviese el mismo convenio que tiene Nafarroa con el Estado, perdería 25.000 millones de pesetas al año». Larrea intervino expresamente contra los argumentos de Unidad Alavesa acompañado de Juan María Ollora, quien dijo que «UA es básicamente anti todo. Es un proyecto basado en el rencor y en el agravio; es insolidario». El PNV se había visto obligado a intervenir como lo había hecho, porque no se podía «digerir tanta mentira». De todos modos, no entraba en los planteamientos del PNV alterar el reparto de escaños atribuido a cada Territorio Histórico según el Estatuto de Autonomía ${ }^{122}$.

En el mitin central de la campaña en Alava Ardanza calificó a los dirigentes de UA de «alavesistas de profesión y foralistas de conveniencia», que trataban de meter «el miedo en el cuerpo, el odio en el alma y el complejo y la envidia en el corazón» del pueblo alavés e insistió en el papel positivo jugado por las inversiones del Gobierno Vasco en la agricultura, industria, servicios sociales e intraestructuras. Fue en este mitin en el que Ardanza insitió de una manera especial en la necesidad de recuperar la unidad nacionalista. «No hay ya razón — dijo — para tanta ruptura y tanta fragmentación. Por eso quiero invitar a los nacionalistas a superar el pasado y a unirnos por la renovación de Euskadi»123.

El alavesismo no era nada nuevo y Unidad Alavesa no tenía ni idea de lo que era el foralismo. Detrás de UA sólo estaban los que querían castigar al Partido Popular. Esta deficiente interpretación de Arzalluz se completó con la añadidura, dicha en el mismo mitin de Vitoria, de que «si algún territorio ha sufrido y está disminuido, ese es Bizkaia. Los alaveses creen que llorando consiguen cosas, pero lo único que logran es estropear el carácter. Gasteiz es la punta de lanza de la industria vasca»124. Félix Ormazabal, por el contrario, tal como lo había hecho Ardanza, des-

\footnotetext{
121 Correo 16, 27.

122 Ver para todo lo indicado en este largo párrafo Deia 19, 4.

123 Correo 16, 27. Ver Deia 16, 8.

124 Deia 16,8 .
} 
tacó la gravedad del problema. Calificó de «escandaloso y desintegrador» al proyecto político de UA y fue certero al considerar que tal proyecto iba «directamente contra la línea de flotación de la construcción nacional de Euskadi, tanto por sus objetivos como por la estrategia» que utilizaba. Si bien Unidad Alavesa era el invento de un «emigrante sedicente», detrás de UA había «algo más»125.

La afirmación de Ollora de que Unidad Alavesa tendría siempre enfrente al PNV, mientras pretendiese que los nacionalistas se sintieran extraños en Alava ${ }^{126}$, la completaba Ardanza, ya casi al final de la campaña, al apelar al «orgullo, la dignidad y la nobleza del pueblo alavés» para rechazar la oferta electoral, que buscaba la separación de Alava del resto de Euskadi. A Ardanza le preocupaba precisamente que Unidad Alavesa buscase «un amejoramiento del fuero como el navarro; es decir, la disgregación de Alava del proyecto común vasco»127.

La denuncia de los planteamientos de disgregación apareció también con ocasión de la formación del Gobierno y de los posibles resultados electorales de las elecciones municipales, que, de ser semejantes a los esperados en las autonómicas podrían, en opinión de Ardanza, producir la quiebra de la cohesión territorial, «máxime teniendo en cuenta la apelación constante que estos últimos días está haciendo Unidad Alavesa tanto al PSE-EE como al PP denunciándoles de traidores si no rompen con el PNV y asumen el compromiso de formar un gobierno no nacionalista en Araba y pasar a la definitiva ruptura y disgregación de este territorio del proyecto común» ${ }^{128}$.

Del Partido Popular $(21,29 \%$ de la crítica a Partidos, que resulta un 9,48\% del total de la campaña) se dijo cuanto se ha anotado respecto al Partido Socialista por su condición de representante o parte de la España opuesta y diferente a Euskadi. Si se exceptúa lo dicho contra los socialistas por su función de Gobierno, todo lo incluido en la sección, tan electoral, por otra parte, de la oposición Madrid-Euskadi, se refiere también al Partido Popular. Baste decir que expresamente se defendió que para Aznar las elecciones vascas no eran otra cosa que un pretendido peldaño para acceder a la Moncloa ${ }^{129}$ (de ahí el grito de Arzalluz: «¡A qué viene a hablarnos de España!» ${ }^{130}$ o la afirmación de que «ha venido trayendo Es-

\footnotetext{
125 Deia $16,8$.

126 Ver Deia 19, 4.

127 Correo 21, 19.

128 Deia 21, 4.

129 Correo 22, 19.

130 Correo 20, 19.
} 
paña, que para él es urgente y para mí no tiene ninguna urgencia»131) o que el Partido Popular actuaba cobardemente ante las manifestaciones de Unidad Alavesa alegrándose de que se fomentara el odio y de que se debilitara Euskadi ${ }^{132}$.

Carácter de exclusiva tiene la acusación, que era, a su vez, respuesta a otra popular según la cual la sociedad vasca estaría caminando hacia su suicidio por obra y gracia del nacionalismo, de que «los que han llevado a este país desde hace decenios a situaciones que suponen la muerte, porque son callejones sin salida, ha sido la derecha integrista; por tanto que no pasen a nadie una pelota que es su propio invento». Arregi recordó al Partido Popular que la situación vivida durante el franquismo en el País Vasco nunca más volverá a repetirse. «La memoria histórica —añadióes muy importante para no volver a cometer los errores del pasado» ${ }^{133}$.

«Fascista mal reinsertado» fue llamado Gregorio Ordónez ${ }^{134}$, mientras que Aznar, acusado de politizar el proceso de reinserción ${ }^{135}$, era considerado poco demócrata por sus declaraciones sobre el Estatuto ${ }^{136}$. Las llamadas de Aznar a la lealtad con el Estatuto Vasco y la Constitución se interpretaron como la defensa del anquilosamiento del proceso de autogobierno vasco y como una interpretación restrictiva de las posibilidades constitucionales ${ }^{137}$.

Uno de los puntos comentados, que afectaba tanto a ETA como a Herri Batasuna, fue el de la ausencia de atentados durante la campaña. Evidentemente, esto se dijo ya superado el ecuador de la misma, pero al principio Juan María Atutxa habló de la posibilidad de que ETA aprovechara la campaña electoral para «buscar notoriedad en una situación propicia» con atentados terroristas. De hecho, la campaña se inició en Gernika con la explosión de una lata de gasolina cerca del lugar, en el que el Partido Popular celebraba el acto de apertura. Ello permitió a Atutxa comentar que «estos actos son productos de la chavalería, de cachorros que después van haciendo la carrera para llegar a mayores. Tratan de hacer todas estas chapuzas para mantener una pretendida alarma social». Sobre

131 Deia $22,5$.

132 Correo 16, 27; Deia 16, 8.

133 Deia $9,6$.

134 Correo 10, 15. En Deia 10, 4, es Aznar el acusado de «fascista mal reinsertado». Egibar ya había destacado que el Partido Popular procedía de Alianza Popular, a la que acusó de votar en contra del Estatuto de Autonomía y de los artículos 1 y 2 de la Constitución, donde se recoge el término nacionalidad (Deia 9,6$)$.

135 Correo 13, 17.

136 Deia 8, 5.

137 Correo 9, 26; Deia 9, 6. 
la posibilidad de atentados comentó: «Una banda que se dedica al chantaje, a la extorsión, a llevar la angustia a miles de hogares de esta sociedad, puede hacer cualquiera cosa. No es un simple temor, es que tenemos al zorro dentro del gallinero y en cualquier momento puede producirse un atentado... no es un temor aislado o circunstancial, porque hay gente con armas mortíferas en la mano y, además, son una cuadrilla de descerebrados». Atutxa pensaba que, si bien mucha gente de Herri Batasuna quería que ETA dejara de matar, no lo manifestaría, porque no podía; menos aún lo haría la Mesa Nacional de HB, ya que la dominaba KAS ${ }^{138}$.

Ante la inexistencia de atentados, pasada ya la primera semana de campaña, Ardanza manifestó su deseo y confianza de que tal hecho fuera consecuencia «no de su debilidad o de su impotencia, sino de una seria reflexión. Espero que superemos la violencia la próxima legislatura, no tanto porque seamos capaces de convencerles, como porque ellos mismos vean que se quedan sin apoyos» ${ }^{139}$. Dos días más tarde, se repitió el comentario con las mismas palabras de «reflexión»y «debilidad», a las que se añadieron las siguientes: «Si es porque se han dado cuenta de que perjudican electoralmente a $\mathrm{HB}$, que ahuyentan votos, querría decir que se están dando cuenta de que con sus métodos están frustrando su propio proyecto político, con lo que podría empezar a confiarse en que pronto podamos empezar a ver la luz de la paz» 140 .

Ardanza no había tenido en cuenta el atentado contra el vehículo particular del viceconsejero de Interior en funciones, José Manuel Martiarena, sobre el que Atutxa comentó: «Tratan de amedrentarnos y no conseguirán acallar nuestra voz» ${ }^{141}$. Al día siguiente volvió a repetir que «aunque nos amenacen y nos quemen el coche seguiremos igual, porque no nos gustan las mafias ni en Sicilia, ni aquí, ni los que hacen huelgas de hambre comiéndose chuletones» ${ }^{142}$. Ardanza sí comentó acerca de los ataques sufridos por el batzoki de Bergara y por un oficina electoral del PP en Gazteiz que detrás de todo ello estaba la intolerancia, el fanatismo, es decir, «la cultura de la cutrez de HB» ${ }^{143}$. De todos modos, la tesis defendida y expresamente manifestada en el último acto de campaña fue la de que la ausencia de atentados era «un paso hacia la normalización»144. En la víspera, el mismo Ardanza había manifestado su satisfacción por la

\footnotetext{
138 Deia $8,5$.

139 Correo 17, 22.

140 Correo 19, 21.

141 Deia 17, 5.

142 Correo 20, 19. Ver Deia 20, 4.

143 Deia 14, 8. Ver también, Correo 14, 19.

144 Correo 22, 19.
} 
campaña convencional realizada por Herri Batasuna sin la «colaboración paralela que le solía prestar ETA con sus atentados. Pienso que se han dado cuenta de que el terrorismo ya no vende. Ojalá no sea una mera táctica de campaña para tratar de salvar algunos votos y que esta actitud se mantenga después del día $23 »^{145}$.

La razón, que expresa o tácitamente se manifestaba como base de esta interpretación, era el rechazo social hacia la violencia, que poco a poco habría alcanzado a parte de los votantes de Herri Batasuna, pero no a la dirección de la misma. Por eso, en la misma línea de argumentación, se preveía una notable abstención en los habituales de HB, tal como había ocurrido en las elecciones europeas, ya que no se había producido ninguna rectificación ${ }^{146}$, y se pedía a los sectores verdaderamente abertzales de HB que congelaran su voto el día 23 de octubre y no lo sacaran del «frigorífico» hasta que los líderes de KAS — «unas personas que, amparándose en una sigla de cobardía que no tiene siquiera personalidad jurídica, cual es el Kas, tratan de llevar a esta sociedad a la ruina»147no cambiasen de criterio ${ }^{148}$. En el mismo sentido, se exigió a KAS que informase de la «verdad» manifestada por el IRA y el Sinn Fein y que no hiciese política utilizando a los presos, negándoles la libertad de la que disfrutaban los dirigentes de $\mathrm{HB}^{149}$. Si, después de esto, eran verdaderamente abertzales, «en el camino — dijo Egibar- nos encontraremos. Lo

145 Correo 21, 19. Ver Deia 21, 4, donde Ardanza manifiesta, de nuevo, su esperanza de que la inactividad de ETA fuese consecuencia de la reflexión sobre la inutilidad de la violencia y no de un momento de debilidad. En Deia 22, 5, Arzalluz manifiesta la posibilidad de que el comportamiento de ETA pueda deberse a una petición expresa de Herri Batasuna, que se habría dado cuenta de que los atentados no le favorecían. En cualquier caso, no era la incapacidad de ETA la explicación del fenómeno.

146 Correo 9, 26.

147 Deia 10, 5.

148 En Deia 10, 5, Atutxa pide al colectivo del «voto sincero» de HB que retire transitoriamente su voto «en espera de que esos iluminados hayan sido capaces de reflexionar dos minutos y de reconducir su estrategia por la vía que esta sociedad ha adoptado para la defensa de sus intereses».

149 En Deia 10, 4, Egibar dijo contra las Gestoras pro-Amnistia y a Senideak: «¿Por qué en lugar de pedir "Presoak kalera" ahora piden «Presoak Euskal Herrira", pero en la cárcel? Porque no tienen capacidad de hacer política al margen de los presos. Yo les sugiero que ofrezcan a los presos la posibilidad de gozar de nuevo de la libertad, que gocen de la misma condición de Idígoras, de Rufi Etxeberria, de Floren Aoiz o de Karmelo Landa». En El Mundo del País Vasco 19, 11, como respuesta a la pregunta de «¿Por qué desde la izquierda abertzale se niega a los presos el derecho individual a la reinserción?», se afirma: «A los presos no se les niega desde la izquierda abertzale ningún derecho, sino que lo que se hace es defender sus derechos individuales y colectivos. Quien está negando derechos, y hasta derechos humanos a los presos políticos vascos, es el Gobierno español y los que se están aliando con él, como la dirección del PNV». 
malo es que en el camino vamos a ver a muchos de estos de HB instalados en IU o el PSOE. No se atreven, tienen miedo a la libertad» 150 .

Según Egibar, lo que el IRA y el Sinn Fein les habían manifestado a los de HB era que habían abandonado la lucha armada de forma incondicional a cambio de la esperanza y del desafio de recorrer un largo camino hacia la soberanía por medios democráticos ${ }^{151}$. «Gerry Adams - repitió Ardanza - les ha dicho (a los chicos de la revolución pendiente) lo mismo que les venimos diciendo nosotros. Que su guerra está perdida». No había más camino que «abandonar la lucha armada y sentarse a hablar, sin condiciones y sin garantías finales, como todo el mundo» ${ }^{152}$.

Atutxa no estaba dispuesto a dialogar en ETB con quienes no accedían «a las foros parlamentarios» y, respondiendo a la acusación de HB de que el PNV se había quitado la careta al presentar por cabeza de Bizkaia a un policía, manifestó que eran los «muchachos de Pepe Rei y de Itziar Aizpurua los que tenían que dar la cara y quitarse la careta ${ }^{153}$. La paz necesitaba tolerancia, abandono del cinismo de los radicales abertzales y la decisión de los «estrategas de KAS» de ordenar «la paralización de tanto traqueteo de metralletas y explosión de bombas. Ese es el camino para ir hacia la paz. La paz no está en Santo Domingo. Está aquí y esta sociedad se la exige» ${ }^{154}$. El mismo Atutxa manifestó su vergüenza, en relación con la pacificación, de «ser un hecho aislado en la Europa Occidental»155.

Del resto de Partidos Políticos se habló muy poco. Izquierda Unida fue censurada, en buena parte, con los mismos argumentos, que pretendían presentar al PSOE y al PP como lo ajeno y extraño al País Vasco, a sus intereses y a sus problemas. Pero no faltó el ataque personal, presentado como autodefensa, con ciertos tintes barriobajeros: «¿Quién es Anguita para llamarme a mí aldeano? Yo seré de pueblo y él de ciudad, pero ¿acaso ha pisado tanto mundo como yo? Conoce tantos países como yo?» ${ }^{156}$ Lo que le pedía Arzalluz, autor de las palabras anteriores, era que se marchase de Euskadi «con su leninismo fracasado, porque aquí ya tenemos a los de KAS»157.

Por dos veces se habló de que las declaraciones de Javier Madrazo acusando al PNV de robar millones al pueblo eran de juzgado de guar-

150 Correo 10, 15 y Deia 10, 4.

151 Deia 10, 4.

152 Correo 22, 19.

153 Deia $16,11$.

154 Son palabras de Atutxa en Deia 22, 4.

155 Deia 10, 5.

156 Deia 10, 4. Ver también, El País 10, 17.

157 Correo 10, 15. En El Mundo del País Vasco se dice que Anguita es un «leninista dogmático» con pretensiones de dar «lecciones de apertura». 
dia, declaraciones que podían dar lugar a una interposición de querella por parte del PNV ${ }^{158}$. Tales declaraciones se enmarcaban en una campaña de IU sobre la corrupción, que fue calificada de delictiva. «Hurgar en este tipo de heridas - dijo Arzalluz- es cuestión de tácticas electorales y mientras que a Javier Madrazo parece que eso le gusta, al PNV no» ${ }^{159}$.

Eusko Alkartasuna fue un Partido electoralmente ignorado. Sólo fue recordado para resaltar su campaña esencialmente contraria al Partido Nacionalista Vasco ${ }^{160}$ y para destacar que la escisión por él protagonizada carecía de sentido. "Creo - manifestó Ardanza en una entrevistaque las cosas se van decantando de manera natural y vamos a ver si somos capaces de acelerar un poco esa reacción, haciendo ver a esa mayoría nacionalista que la única opción nacionalista democrática útil es la del PNV... Hace ocho años no nos podíamos imaginar que la quiebra que sufrimos (la escisión) la íbamos a tener prácticamente superada en 1994»161. Esta interpretación optimista coincidía con las palabras de Ormazabal: «EA no es más que un residuo al que no le queda más que interpretar el acto final»162. Pero hubo una llamada un tanto angustiosa a la unión, provocada por los fenómenos de desintegración denunciados por el PNV y, en concreto, ante los objetivos de Unidad Alavesa, que ya ha quedado consignada, cuando Ardanza invitaba a olvidar el pasado y conseguir la unidad de los nacionalistas para la renovación de Euskadi ${ }^{163}$.

158 Correo 14, 19 y Deia 22, 5.

159 Deia 21, 4.

160 Correo 22, 19 y Deia 22, 5.

161 Correo 21, 26.

162 Correo 19, 21.

163 Sobre la campaña del PNV, además de todos los lugares citados, se puede consultar en el diario Egin lo siguiente: 8, 11 (debate en la cadena Ser); 8, 13 (Pacto de Ajuria Enea y violencia); 9, 13 (entrevista Ardanza-Garaikoetxea); 9, 20 (sobre la potenciación del Departamento de Agricultura y Pesca); 10, 16 (mitin de Anoeta); 12, 13 (transferencia de la Seguridad Social); 13, 12 (Pacto de Ajuria Enea y pacificación); 14, 7 y 11 (pacificación, PSOE e IU); 16, 9 y 11 (mitin en el Teatro Principal de Gazteiz); 17, 9 (nacionalismo español, origen de la violencia en Euskadi); 18, 14 (apoyo de independientes al PNV); 19, 17 (documento contra Unidad Alavesa); 20, 13 (mitin de Barakaldo); 21, 11 (balance de la campaña y futuro Gobierno); 22, 14 (mitin de la Casilla, en Bilbao). Otras aportaciones se encuentran en $E l$ Mundo del País Vasco 8, 9 (mitin de Eibar y rueda de prensa de Ardanza); 9,9 y 15; 10, 9; 11,$7 ; 12,11 ; 13,11 ; 14,6 ; 15,14$ (sobre la construcción nacional); 16, 16;17, 6 (sobre el nacionalismo español); 18, 8; 19, 6;20, 6;21, 10 y 11 (entrevista a Ardanza sobre corrupción, renuncia a la crítica a EA, respeto sin lealtad a la Constitución, inexistencia del concepto de Estado soberano de Sabino Arana; poder político de la nación vasca: el de cualquier otra en Europa; nacionalismo español: identificación del Estado y Nación; preocupación por la división nacionalista; Gobierno de coalición; 22, 6. En El País 21, 18 hay una entrevista a Ardanza. 


\section{LA CAMPANA DE EUSKO ALKARTASUNA}

\section{Datos básicos}

La campaña de Eusko Alkartasuna ocupa en la prensa un espacio más reducido que la del Partido Nacionalista Vasco. Tomando como unidad base (100) el espacio de la campaña del PNV, el de EA es casi un $18 \%$ menor $(82,87 \%)$, si bien es un $8 \%$ mayor que el de Herri Batasuna. Esta diferencia cuantitativa no parece afectar a ningún aspecto esencial de la campaña electoral y no manifiesta necesariamente, aunque sí probablemente, una campaña objetivamente más limitada.

La distribución del espacio es la siguiente: Un 52,30\% describe la imagen de Partido y un 47,69\% critica diversos aspectos de los demás Partidos Políticos.

La imagen de Partido se creó fundamentalmente a través de temas esencialmente nacionalistas o afines al nacionalismo, según los criterios utilizados hasta ahora. La definición nacionalista de EA ocupa el 56,53\% de la imagen, siendo el 29,56\% del total de campaña. Autogobierno, utilidad del nacionalismo, Estatuto Vasco, autodeterminación, Estado Vasco y una constante insistencia en presentar a EA como un Partido nacionalista distinto de los demás y como el auténtico nacionalista defensor de la esencia del nacionalismo, fueron los puntos de este espacio. Destaca sobre todos ellos éste último con el $58,7 \%$, que equivale al $33,18 \%$ y al $17,35 \%$ de la definición de Partido y del total de la campaña, respectivamente. Del resto de cuestiones sólo tiene relevancia lo relativo al Estado Vasco - términos que pocas veces aparecen expresamente y que lamentablemente en algunas informaciones se identifican con el concepto de autodeterminación- con el 23,63\%, que equivale al 13,36\% de la definición de Partido y al 6,98\% de la campaña.

Las cuestiones programáticas llenaron el 38,03\% (19,89\% de la campaña), entre las que se incluyeron los temas de pacificación, terrorismo, Pacto de Ajuria Enea, igualdad entre los sexos, reivindicaciones sociales, euskera, corrupción, reforma de la Ley de Territorios Históricos y petición del voto. De todos estos temas únicamente tuvo relevancia lo relativo al Pacto de Ajuria Enea (pacificación y terrorismo incluidos), que ocupa el $37,06 \%$ de este espacio $(14,09 \%$ de la imagen y $7,77 \%$ de la campaña), y, en menor medida, los contenidos sociales y la justificación de la petición de voto.

El futuro Gobierno tuvo una atención muy reducida, que sólo alcanza el 5,43\% de la definición del Partido (2,84\% de la campaña).

La crítica de los Partidos Políticos, que alcanzó el 47,69\% de la campaña, se centró fundamentalmente en el Partido Nacionalista Vasco. Este 
acaparó el 63,44\% de las críticas, lo que equivale al 30,26\% del total de la campaña. Según esto, casi una de cada tres palabras de Eusko Alkartasuna fue dicha contra el PNV. El resto de críticas se lo repartieron los Partidos Políticos de la siguiente manera: Partido Socialista de EuskadiEuskadiko Eskerra, 19,80\% (9,44\% del total de la campaña); Unidad Alavesa, 5,95\% (2,84\%); Partido Popular, 4,66\% (2,22\%); Herri Batasuna, 2,89\% (1,38\%); EUE, 2,09\% (0,99\%); Izquierda Unida, 1,12\% (0,53\%). De donde se deduce que electoralmente sólo hubo para Eusko Alkartasuna dos adversarios: Los que habían integrado la coalición de Gobierno anterior.

La campaña de Eusko Alkartasuna fue la campaña de Carlos Garaikoetxea. El 78,89\% se atribuyó al Presidente de EA; el 11,84\% a Jasone Iraragorri; el $2,88 \%$ a Oliveri; el $0,22 \%$ a Ormazabal y el $6,15 \%$ a Pilar Rahola del Partido catalán ERC, que intervino en la campaña a favor de Eusko Alkartasuna.

\section{Desarrollo de la campaña}

\section{A) La definición o imagen de Partido}

\section{El nacionalismo de Eusko Alkartasuna}

Si casi una de cada tres palabras tuvo al PNV como destinatario para destacar su carácter conservador y regionalista, casi, también, la misma cantidad de palabras se dedicaron a identificar a Eusko Alkartasuna como Partido progresista y abertzale. Ambas cuestiones fueron inseparables. La manera tan persistente y reiterativa de proclamar los componentes ideológicos definitorios parece que se quiso fundamentar en diversas razones. Una tendría que ver con el tipo de adhesión, muy emocional y personal, que acompañó al origen del Partido. Su sustitución por una adhesión basada en motivos ideológicos explicaría la insistencia en los mismos. Una segunda razón iría unida a la desmovilización y disminución de la conciencia nacionalista en la sociedad vasca. Y, por último, las necesidades electorales derivadas de competir con otros Partidos nacionalistas. En cualquier caso, «pensar que el nacionalismo es algo homogéneo es un error. Así como en los Estados español y francés hay opciones políticas, dentro del nacionalismo vasco también hay progresistas y reaccionarios, gentes de extrema izquierda y gente de extrema derecha» 164 .

164 Correo 13, 25. En algún momento Garaikoetxea calificó las diferencias de «matices», término que parece poco correcto para semejante objetivo (Ver Correo 14, 24). En Correo 19, 17, se critica que el PNV pretendiese ser en exclusiva la voz de los vascos. 
El punto de partida del nacionalismo de EA se fundamentaba en la existencia «de un contencioso entre el Estado español y las aspiraciones nacionales de Euskal Herria», que de ninguna manera podía reducirse a un problema entre vascos ${ }^{165}$.

Tal nacionalismo se concretó positivamente en la defensa tácita del Estado Vasco independiente y en la defensa expresa de la autodeterminación, como su punto de partida, y del autogobierno, concepto que se utiliza en un sentido sumamente amplio, que iría desde las competencias del Estatuto hasta la misma independencia o emancipación nacional, que sería así la culminación del autogobierno ${ }^{166}$. La razón de la independencia - expresamente defendida ${ }^{167}$ — era netamente nacionalista, pero destacaba su carácter funcional y utilitario. EA trataba de acallar la opinión

165 Correo 10, 26. Ver Egin 10, 16, donde Garaikoetxea repite la idea de que es falso reducir el problema de Euskadi a un problema entre vascos. «Existe — dijo- un contencioso entre el Estado y el pueblo vasco y sus aspiraciones nacionales... No podemos permitir que se proyecte una especie de eclipse total sobre el conflicto político con el Estado que no da cauces suficientes para alcanzar las cotas de autogobierno del pueblo vasco... Estaremos en primera línea frente a la violencia, pero no haremos ningún pacto con partidos estatales mientras su actitud democrática no les comprometa a aceptar la necesidad de asumir lo que pacífica y democráticamente decida este pueblo». La coincidencia con HB era en algunos objetivos, pero no en los métodos. En El Mundo del País Vasco 18, 11, Garaikoetxea responde así a la pregunta de si cree que existe una ofensiva del nacionalismo español contra el sentimiento nacional vasco: «En los términos un tanto agresivos y por cierto de circunstancias electorales que suele emplear Arzalluz yo no diría las cosas. Yo simplemente constataría con naturalidad que ciertamente aquí hay un problema, un contencioso irresuelto, una cuestión nacional, y eso implica efectivamente la consolidación de dos sentimientos nacionales. Un sentimiento nacional, expansivo, centrípeto o como se le quiera llamar y una reivindicación nacional, un movimiento de emancipación nacional que naturalmente entra en colisión con el anterior, pero que a mí me gustaría siempre plantear en términos pacíficos, con racionalidad, desde la constatación de que nuestro sentimiento nacional, nuestra reivindicación nacional, si fuera posible, tendría que resolverse desde la cordialidad con pueblos como los pueblos del Estado español, con los que hemos tenido tantas afinidades históricas, culturales, innegables. De manera que me parece desafortunado el lenguaje que le da un aire de hostilidad y hasta de confrontación trágica del asunto. Yo prefiero plantear esta confrontación de sentimientos nacionales desde la advertencia de que luego los pueblos, aun después de las emancipaciones nacionales, tienen que recobrar una relación de cordialidad y hasta de fraternidad».

166 En los textos no consta que Garaikoetxea utilice expresamente el término Estado Vasco o independencia nacional, sino los términos de autodeterminación, emancipación nacional o, simplemente, Euskadi o País Vasco. Aunque éstos no excluyen el sentido que les da la información, no lo suponen necesariamente. Sabin Intxaurraga utiliza el término «Estado propio» al afirmar que EA «nunca abandonará su pretensión de crear un Estado propio en el contexto europeo, pero siempre por medios pacíficos y sin atentar contra la voluntad soberana del pueblo» (El Mundo del País Vasco 9, 14).

167 Pilar Rahola, representante de Esquerra Republicana de Catalunya, destacó la coincidencia con EA en cuatro puntos: Ideología progresista de izquierda no dogmática, reivindicación de una nación independiente, lucha contra la corrupción y relevo generacional (Correo 19, 17). 
de que la independencia fuese una cuestión meramente romántica, que debía ser abandonada por su inutilidad. Se partía del hecho de que los intereses del País Vasco estaban supeditados a otros intereses estratégicos, definidos, sin intervención vasca alguna, por el Estado central. La pretensión nacionalista consistía en lograr una capacidad de dar respuestas propias a intereses y problemas propios. «Conseguir la autodeterminación -obsérvese que no se usa el término Estado utilizado por el periodista- significa tener capacidad de interlocución en los ámbitos internacionales, significa que cuando en Maastrich, en Bruselas o en Edimburgo se negocian cuestiones que afectan a la pesca o a los viñedos, seremos nosotros, y no otros, los que defiendan los intereses de Euskadi... Es tener capacidad para investigar, tener un marco autónomo de relaciones laborales para poder salir de la crisis o impedir que vuelvan a quedar sin retornar al País Vasco 500.000 millones por cotizaciones a la Seguridad Social, como ha pasado en los últimos diez años» ${ }^{168}$. La autodeterminación no se interpretaba como la solución de todos los problemas, pero se insistió en que, por un lado, no era decente contraponer la solución de los problemas prácticos con el autogobierno o la autodetermianación ${ }^{169}$, y, por otro, la disminución de la conciencia nacionalista se debía tanto a no haber utilizado el autogobierno como instrumento de desarrollo y en haber creído «la promesa vendida desde el nacionalismo (se supone que del PNV) de que Europa solucionaría nuestros problemas» ${ }^{170}$. Garaikoetxea reiteradamente defendió el autogobierno desde una perspectiva «no exclusivamente sentimental sino práctica, enfocada a la solución de los problemas de los ciudadanos» ${ }^{171}$.

Se intentaba presentar un nacionalismo actual, superador del nacionalismo decimonónico, y ello se concretaría, según el informador, en el concepto de Estado, aduciendo el siguiente texto, que en realidad no demostraba ninguna novedad nacionalista: «Euskadi estaría en el marco europeo respetando las reglas de intercambio comercial, con fronteras abiertas, sin aislamientos y autarquías económicas» ${ }^{172}$.

Este nacionalismo, presentado como realista y objetivo, descubría su utopía política y su finalidad electoral con estas palabras: «Todo sería

168 Correo 16, 34. El mismo sentido aparece en Correo 18, 25.

169 Ver Correo 18, 25. En esta misma cita se repite el concepto de autodeterminación: «Queremos autodeterminación para poder defender a los arrantzales, a los viticultores, a los ciudadanos vascos en los foros internacionales donde se toman las decisiones; ese es el sentido de nuestra reivindicación».

170 Deia $19,8$.

171 Deia 19, 3. Egin 19, 13: era una «falacia que ha hecho mucho daño al nacionalismo la pretensión de separar ambos conceptos» (autogobierno y solución de los problemas de los ciudadanos).

172 Ibidem. 
así, salvo que alguien quisiera venganza por nuestra emancipación nacional, alguien que quisiera gestionar un boicot para nuestra existencia. Pero esto no podríamos esperarlo de quienes se dicen nuestros más cordiales vecinos» ${ }^{173}$. EA, por el contrario, consideraba que la autodeterminación era compatible con una convivencia solidaria entre los pueblos ${ }^{174}$.

El mensaje de EA era netamente abertzale, porque, según su opinión, luchaba «sin ambigüedades por la autodeterminación y la configuración de una nación vasca»175. Precisamente en su radicalismo abertzale se veía uno de los motivos de la pérdida de apoyo electoral. «A veces, la expresión clara de unas metas ideológicas resta adhesiones emocionales. Y en ese sentido, la picaresca de la ambigüedad puede ser más rentable a corto plazo. Pero, para nosotros, la política no es una máquina de conquistar poder o de establecerse en la vida» ${ }^{176}$.

La autodeterminación era el contenido político fundamental, que reclamaba EA para culminar el autogobierno, colapsado desde hacía tiempo por la aprobación de «leyes básicas del Estado ${ }^{177}$ ». Era necesario «cambiar el marco jurídico para ejercer la autodeterminación» ${ }^{178}$, de manera que el pueblo pudiese libremente «fijar la fórmula de Estado»179. Esto no suponía el rechazo del Estatuto o de su validez histórica y actual, ni el abandono de la negociación para conseguir las transferencias pendientes - precisamente Garaikoetxea insistiría en la necesidad de negociar con decisión y dureza-, pero sí el reconocimiento, por un lado, de que, una vez que se culminasen las transferencias, tal vía quedaría agotada, y, por otro, el reconocimiento de que desde 1984 no se habían producido transferencias importantes ${ }^{180}$. Garaikoetxea defendió la necesidad de reformar el Estatuto, para lo cual, pensaba, era necesario un nuevo consenso entre las fuerzas políticas. A falta de tal consenso, había que respetar lo que existía ${ }^{181}$.

Negativamente se definió el nacionalismo de EA comparándolo con el del PNV y Herri Batasuna. Ni nacionalismo moderado y reaccionario del PNV, ni radicalismo de HB. «Nosotros no pedimos blanco o negro, posturas extremas que son más fáciles de identificar. No nos alineamos ni con el nacionalismo moderado ni con el radicalismo asilvestrado. Exi-

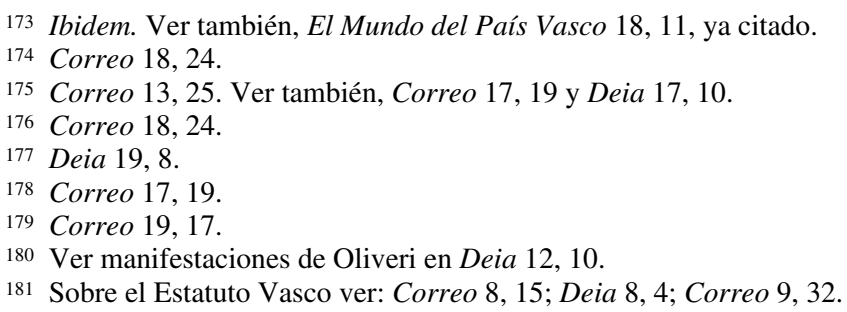


gimos con igual firmeza las reivindicaciones nacionales vascas y el cese de la violencia, porque no estamos ni con el infantilismo revolucionario ni con las tesis conservadoras clásicas» 182 .

$\mathrm{Ni}$ violencia terrorista ni corrupción. «Frente a la ola conservadora - dijo Garaikoetxea-, es importante un partido que en Europa no esté aliado con Aznar, Fraga, Thatcher o Major, como lo hace el PNV. Pero también un partido que no confunda el progreso con la quema de autobuses, con la algarada callejera y los tiragomas»183. La misma idea aparece en manifestaciones de Jasone Iraragorri: «Estamos instalados entre el conservadurismo de derechas del PNV y los violentos»184.

El nacionalismo de EA era, además, democrático. Repetidas veces se dijo que la emancipación nacional, objetivo último, sería una cuestión a decidir en referéndum por la sociedad vasca, cuyos resultados deberían ser aceptados por todas las fuerzas políticas «lejos de visiones dogmáticas»185. La misma tesis se defendió con respecto a Navarra. «Somos gente consecuente - dijo Garaikoetxea-. Navarra es indiscutiblemente una parte fundamental de Euskal Herria; lo dicen los historiadores, los geógrafos, su toponimia, todo. Otra cosa es que la adhesión a un proyecto político pueda ser deseada o no. Y ahí hemos sido consecuentes al determinar que es algo que atañe a los navarros» ${ }^{186}$. El proyecto nacionalista de EA afirmaba «sin ambigüedad (término utilizado muchas veces tanto para definir la imagen de EA como para censurar la del PNV) la autodeterminación por vías pacíficas y democráticas» ${ }^{187}$.

En resumen y por añadidura, el nacionalismo de EA era, entre el PNV y $\mathrm{HB}$, el único adecuado en y para Euskadi. Algo de esto quiso concluir Iraragorri, cuando dijo: «Nuestro partido es el único referente nacionalista adecuado en Euskadi, de hecho y de derecho, no de disfraz y campanillas, como el PNV, o de guerra de guerrillas, como HB» ${ }^{188}$.

\section{Cuestiones programáticas}

Como le ocurrió al PNV, la pacificación fue la mayor preocupación de Eusko Alkartasuna relativa a este apartado. Y, tal como defendió el Partido Nacionalista, Garaikoetxea mostró la necesidad de acercarse y dialogar con Herri Batasuna, aduciendo como argumento el peso político

\footnotetext{
182 Correo 14, 24.

183 Correo 17, 19. Ver, también, Deia 17, 10.

184 Correo 19, 17.

185 Deia 19, 8. Ver, también, Correo 13, 15; 16, 34.

186 Correo 18, 25.

187 Deia $13,4$.

188 Correo 14, 24.
} 
y social de la coalición abertzale. «Hay que abrir vías de diálogo con quienes representan algo en esta sociedad, y HB, con la distancia abismal que nos separa, representa algo»189.

La cuestión de la erradicación del terrorismo y la consecución de la paz se centró en torno a la validez de la Mesa de Ajuria Enea para conseguir tales fines, aunque no se excluyeron otros procedimientos como el recurso a conversaciones secretas, tal como se había hecho con resultados positivos entre palestinos e israelíes y el IRA y el Gobierno británico. Así se dijo que «dentro de la discreción, si viene la paz, bienvenida sea aunque la traiga el diablo; y nosotros, si hace falta, miraremos hacia otro lado porque no tenemos ningún prurito partidista» ${ }^{190}$. En cuanto a la Mesa de Ajuria Enea se pensaba que el consenso sobre el que se había basado el acuerdo de pacificación lo había roto el Partido Nacionalista al mantener negociaciones paralelas con Herri Batasuna. Hacía falta, pues, un nuevo consenso, que debería incluir ciertas novedades. En primer lugar, el diálogo entre las formaciones políticas debía trasladarse al Parlamento Vasco o a otro lugar, que no sólo garantizase la libertad de expresión y la discreción necesarias, sino, también, la seriedad de las actuaciones y la constancia de los compromisos. «Al decir Parlamento Vasco —explicó Garaikoetxea-, quiero decir un lugar neutro, no manipulable y donde además quede constancia de lo que cada uno promete. Y, por añadidura, que esté abierto a toda fuerza que represente algo en este país. Lo que no queremos es que se repita el "pitorreo" de la Mesa de Ajuria Enea, que el PNV negocie con HB cuando le conviene para quitarnos, por ejemplo, el Gobierno de la Diputación de Guipúzcoa. Es necesario un nuevo foro donde esté presente la seriedad» ${ }^{191}$. En segundo lugar, como ya se ha hecho constar, el diálogo debía estar abierto a todas las fuerzas políticas, incluida Herri Batasuna. Y, en tercer lugar, debía reconocerse por los Partidos de ámbito estatal el derecho de autodeterminación del pueblo vasco ${ }^{192}$.

El progresismo al que tantas veces se refirió la propaganda de EA se concretó en diversos contenidos propuestos en clara oposición al supuesto reaccionarismo y conservadurismo de otros Partidos, especialmente, del Partido Nacionalista. Si en el orden nacional la diferencia con el PNV estaba en la radicalidad y autenticidad de su proyecto nacionalista y

189 Deia 8, 4. Ver, tambien, Correo 8, 15. En El Mundo del País Vasco 8, 9, se dice que hay que «hacer algo más e intentar un acercamiento y un diálogo que nos permita salir de este círculo cerrado en el que nos encontramos».

190 Correo 20, 32.

191 Correo 18, 25.

192 Ver Correo 10, 26. Ver, también, sobre la pacificación y Mesa de Ajuria Enea: Correo 8, 15; Deia 8, 4; Correo 11, 25; Correo 14, 24; Deia 14, 10; Correo 18, 24; Correo 19, 17. 
en la nitidez y claridad de su manifestación, en el orden social la diferencia estaba en la inspiración socialdemócrata que animaba su modelo de sociedad. Era la aceptación de esta ideología la que, juntamente con su radicalismo nacionalista, estaba en el origen del alejamiento de parte del electorado. EA consideraba sumamente importante luchar contra la ola conservadora y reaccionaria que amenazaba a la sociedad vasca. No se podía dar un paso atrás en la defensa del Estado social.

Pero el supuesto carácter progresista tuvo mucho más de afirmación general y de crítica que de riqueza de contenidos, aunque se especificaron algunos: Un pacto social entre empresarios, agentes sociales y la Administración para salir de la crisis económica y luchar contra el paro, la inclusión de la lucha contra el paro como el primer objetivo del siguiente Gobierno, la austeridad, la eficacia y la honestidad en la Administración, la reducción de la misma ${ }^{193}$, la creación de una residencia para disminuidos físicos, la conversión del Plan Integral contra la Pobreza, que tenía carácter extraordinario, en un plan permanente, el traspaso de las competencias sobre bienestar social a los Ayuntamientos, el subsidio de desempleo para los Profesionales Autónomos, la entrega del 0,7\% del Presupuesto para los países del tercer mundo y la defensa de la presencia de la mujer en los puestos políticos ${ }^{194}$.

Ciertos aspectos progresistas en materia política se concretaron en la lucha contra la corrupción, en la participación en las comisiones de investigación contra la misma, en la reivindicación de las listas abiertas en

193 Sobre la necesidad de la reforma de la Administración vasca, cuestión que se utilizaba especialmente como crítica contra el PNV, José Antonio Ardanza manifestó a Deia 16, 5 lo siguiente: «En primer lugar, porque también la Administración tiene que ser una estructura competitiva. Si nosotros estamos tratando de insuflar en la sociedad una nueva cultura, una nueva mentalidad de eficacia, de trabajo, de mínimo costo, ese concepto de competitividad hay que incorporarlo a la Admisnitración de arriba abajo. Ahora bien, la Administración será más o menos en función de las demandas que le haga la sociedad. Lo que no cabe es que la ciudadanía, para la que está creada la Administración, te diga que ésta tiene que ser eficaz y reducidísima, y que por otra parte te esté pidiendo que toda la enseñanza sea gratuita, que toda la sanidad sea gratuita, que le hagas esto o que le resuelvas lo otro. Tiene que haber coherencia en todo esto. La reforma de la Administración no es un acto puntual, como a veces puede entender la gente. ¿Qué es la reforma de la Administración? ¿De trece carteras que tiene ahora el Gobierno, bajar a diez? ¿Y con eso ya se ha hecho la reforma de la Administración? Pues, no. Eso no es la reforma de la Administración. Eso es una partecita muy pequeña de una muestra de voluntad política de hacer que haya un menor costo político en la Administración, pero con eso no se ha resuelto la reforma de la Administración. La reforma de la Administración es algo muchísimo más profundo que eso. Y además nunca terminará. De la misma forma que nunca terminará ese esfuerzo por la competitividad en el que estamos metidos ahora todas las sociedades».

194 Ver Correo 9, 32; Correo 11, 25; Deia 13, 4; Deia 14, 10; Correo 14, 24; Correo 15, 25; Deia 16, 14; Correo 17, 19; Correo 21, 28. El Mundo del País Vasco 8, 9. 
materia electoral y en la exigencia de «mayores cotas de libertad de expresión y de independencia de las instituciones» ${ }^{195}$ y en la propuesta de un código deontológico para los Partidos políticos, que habría de concretarse en una legislación que garantizase, entre otros objetivos, la transparencia en la financiación de los Partidos y en la participación de los mismos en empresas privadas, la instauración de un nuevo régimen de incompatibilidades, la agilización de las comisiones de investigación, la supresión de los fondos reservados asignados a la Lehendakaritza y la imposición de un control parlamentario sobre la partida correspondiente al Departamento de Interior ${ }^{196}$.

El rechazo de un país castellanizado y la defensa, en su lugar, de un país euskaldun, más la reforma de la Ley de Territorios Históricos, a la que se hizo culpable del debilitamiento del Gobierno y Parlamento, de la dispersión de políticas necesitadas de unidad y del aumento desmesurado del gasto público, completaban el proyecto «integrador, renovador y solidario» de EA.

Todo ello justificaba la petición del voto dirigida a los nacionalistas y de un modo particular a tantos desencantados de la política, especialmente de EE y de EUE, a quienes Iraragorri dijo: «¿Qué hubiera sido de este país sin un control de los medios de comunicación independientes y de los partidos de la oposición? Hubiera sido una república bananera... Sólo con su (la de los desencantados) participación conseguiremos cambiar este país. Los que están refugiados en la desilusión tienen que saber que sólo con su voto podremos abrir una cuña en ese muro monolítico. El voto útil es el voto a las formaciones que somos una alternativa». Los nacionalistas debían votar a Eusko Alkartasuna no sólo porque de esa forma se coincidiría con una opción de partido nacionalista, sino porque sería la única forma de evitar que los socialistas repetiesen con el PNV el desastre de Gobierno de las dos últimas legislaturas. La indiferencia y la abstención serían un apoyo a que las cosas siguiesen igual ${ }^{197}$.

\section{Cuestiones de Gobierno}

La máxima electoral «Con EA, Gobierno nacionalista» quiso decir que carecía de lógica y fundamento un Gobierno monocolor del PNV debido a la enorme fragmentación del electorado del País Vasco y que lo

195 Correo 19, 17.

196 Deia 18, 6.

197 Correo 21, 28. Ver sobre estas últimas cuestiones: Correo 17, 19; Deia 17, 10; Deia 18, 6; Correo 20, 32; Correo 21, 28. En Correo 18, 24 se lee: «Lo que ha habido es desilusión por el tipo de política que se hacía, o por el disgusto que producía que el voto no sirviera para nada. El ejemplo típico es San Sebastián: ganamos unas elecciones y al día siguiente se encuentran con alcalde del PSOE puesto por el PNV. Pero a éstos hay que decirles que quedarse en casa significa mantener el "statu quo"». 
previsible era pensar en un Gobierno de coalición. Tal Gobierno sería nacionalista en la medida en que tuviese un programa de construcción nacional vasca. En ese supuesto, EA no tenía ningún inconveniente de participar en una coalición de tres partidos, uno de los cuales podía ser el de los socialistas e, incluso, el Partido Popular, aunque esto sería más problemático y difícil, dado que a las diferencias en la cuestión nacional se añadirían las de clase que se derivaban del progresismo de EA y del conservadurismo del Partido Popular. De todos modos, se matizó que en materia de conservadurismo poca diferencia había entre Partido Popular y Partido Nacionalista. La coalición no podía entenderse como un reparto de poder entre dos partidos, donde una parte neutralizaría a la otra, como había ocurrido en los ocho años anteriores. La coalición debía garantizar que el núcleo más fuerte fuese nacionalista para así poder realizar un programa nacionalista. Por ello, EA, a la espera de los resultados electorales, daría importancia al programa, aunque no sólo al programa, ya que en materia de Gobierno tan importante era la manera de hacer política. La participación en el Gobierno jamás se haría a costa de traicionar las ideas propias ${ }^{198}$.

\section{B) La crítica de los Partidos Políticos}

Aunque la parte dedicada a expresar la definición o imagen de Partido fue mayor que la dedicada a la crítica de los Partidos, sin embargo el tema, se podría decir, monográfico, el tema más veces repetido, fue la censura a los socios de Gobierno durante las dos anteriores Legislaturas, el Partido Nacionalista y el Partido Socialista, alcanzando la cota del $40 \%$ del total de la campaña. Como ya se ha indicado, el 30\% lo acaparó el Partido Nacionalista. Garaikoetxea justificaría esta crítica al PNV por su condición de Partido gobernante ${ }^{199}$.

El PNV, partido con ilógicas $(23,9 \%$ de los votos en las anteriores elecciones) pretensiones hegemónicas y al que no se consideraba «exponente de la sociedad vasca ni de la pluralidad del propio nacionalismo» ${ }^{200}$, fue definido como la derecha regionalista, si bien la campaña prueba que el término «derecha» se mostró insuficiente para su descripción adecuada, ya que sería calificado no sólo de conservador, lo cual entraría dentro del contenido de la derecha, sino de reaccionario e integrista.

198 Ver: Correo 12, 19; Deia 13, 4; Deia 17, 10; Correo 18, 24.

199 El Mundo del País Vasco 18, 10.

200 Deia 12, 10. En El Mundo del País Vasco 18, 10, dice Garaikoetxea: «Yo creo que esa evocación de la casa del padre, de la unificación posible del nacionalismo... es un error, es un tópico quizás alentado interesadamente». 
Tal condición se hacía evidente, según la crítica de EA, en la política de recortes en las prestaciones sociales y en los salarios, en la marginación general del Estado de Bienestar, de lo que era una muestra lo anterior, en la responsabilidad de la crisis económica y de la falta de acuerdo social contra el paro, en el aumento del gasto público hasta el despilfarro de 50.000 millones de pesetas, en la politización partidista de la sociedad, en la conversión del Partido en un movimiento de estómagos agradecidos, en la práctica desde las instituciones políticas del amiguismo y de la corrupción, en el abuso institucional para fines electorales partidistas ${ }^{201}$ y, por supuesto, en la selección de las personas para los cargos de responsabilidad política ${ }^{202}$.

En cuanto regionalista, la dirección del PNV no pasaba de ser autonomista, siendo su nacionalismo una máscara y un instrumento de poder, no un objetivo, y el radicalismo verbal una forma de distraer la atención política de las cuestiones y problemas fundamentales del país evitando así tener que dar cuenta de sus acciones de gobierno durante ocho años. Movido, como el Partido de los socialistas, por la conquista del poder y por la rentabilidad de la coalición con los mismos, el PNV fue acusado de desestabilizar la campaña y de convertirla, tras aparentar un supuesto enfrentamiento con los socialistas, en una representación teatral, en una tomadura de pelo a los electores, y, en definitiva, en un tongo electoral. La destrucción por parte del PNV del consenso inicial de la Mesa de Ajuria Enea y las conversaciones mantenidas con Herri Batasuna demostraban que no había más finalidad y estrategia política que aquellas que convenían a los intereses de un Partido, antes nacionalista, y ahora irreconocible como tal, que tenía una dirección, que ni era de fiar ni defendía los intereses de Euskadi203.

Este esquema se desarrolló desde el principio hasta el fin de la campaña y, tal como se ha visto, fue el procedimiento fundamental, por vía de negación, de la definición del nacionalismo y progresismo de Eusko Alkartasuna.

Apenas iniciada la campaña, Garaikoetxea acusó a Ardanza y a Jáuregui de tratar a los «ciudadanos como si fueran imbéciles», pretendiendo «confundirles con enfrentamientos ficticios y declaraciones estridentes» ${ }^{204}$, y dejando de lado la explicación de la falta de un acuerdo social contra el

201 Ver sobre uso partidista de las instituciones Correo 22, 26.

202 En Correo 21, 28 se lee: «Habla de renovación y entre los candidatos a sustituir a Pradera figuran Bergara y Javier Atutxa, dos representantes del integrismo nacionalista puro y duro».

203 Correo 22, 26.

204 Correo 11, 25. 
paro y, sobre todo, pretendiendo renovar de nuevo la coalición, que había llevado al Ejecutivo vasco a pasar de unas deudas de 55.000 millones en 1987 a 224.000 millones en 1993 y a que Euskadi tuviese 80.000 parados más que hacía cuatro años con una pérdida de 40.000 puestos de trabajo $^{205}$.

Pasado el ecuador de la campaña, las agresiones entre PNV y PSE-EE fueron calificadas de «falso debate» 206 . Y la conclusión final fue que «el PNV y PSE-EE (habían) hecho tongo al intentar aparecer en la campaña como dos partidos enfrentados». El enfrentamiento había sido ficticio y los debates se habían eludido. «Han utilizado — dijo el Presidente- a HB para no dar la cara. Llevan ocho años como socios en el Ejecutivo vasco y realizan una política común en Madrid y, sin embargo, han intentado aparecer como rivales hasta el final, hasta que el señor Arzalluz ha desvelado sus planes de volver a gobernar con los socialistas»207. Así se renovaría el pacto «vergonzoso», que había impedido las investigaciones necesarias para aclarar los casos de corrupción ${ }^{208}$ o que había agudizado la crisis económica ${ }^{209}$, y que «significaría perder otros cuatro años, además de los diez anteriores, que han sumido a Euskadi en la peor situación conocida» ${ }^{210}$. EA llegó a interpretar el apoyo de los socialistas al Gobierno anterior como la contrapartida para que el PNV apoyara la Ley Corcuera en las Cortes, guardara silencio en torno al caso de los GAL e impidiese la investigación de los casos ya mencionados ${ }^{211}$.

De este modo, el voto al PNV era un voto a los socialistas. Tal como había ocurrido con la entrega a los socialistas de instituciones fundamentales en Guipúzcoa ${ }^{212}$, lo mismo ocurriría en el futuro. «Los ciudadanos de este país — dijo Garaikoetxea- ya saben, por boca de Arzalluz, que votar al PNV es votar al PSOE, que el que vota al PNV es para que vuelva a haber un consejero de Educación socialista, un consejero de lo que sea del PSOE, medias diputaciones del PSOE, medios ayuntamientos del

205 Correo 11, 25.

206 Correo 17, 19.

207 Correo 22, 26. Ver, también, Deia 12, 10, donde Inaxio Oliveri afirma: «El PNV y el PSE, después de andar tirándose los trastos a la cabeza parece que han comenzado la etapa de la reconciliación de manera que les conduzca a reeditar la coalición en la próxima legislatura».

208 Ver Deia 13, 4. En Correo 19, 17, se citan los casos «casinos», «tragaperras» $\mathrm{y} « F i-$ lesa».

209 Ver Deia 17, 10.

210 Palabras de Inaxio Oliveri en Deia 12, 10. Ver también, intervención de Carlos Garaikoetxea en Correo 21, 28 y Correo 22, 26.

211 Correo 17, 19.

212 «El ejemplo típico es San Sebastián: ganamos unas elecciones y al día siguiente se encuentran con alcalde del PSOE puesto por el PNV» (Correo 18, 24). Ver también, Deia 13, 4. 
PSOE. Si los votantes nacionalistas quieren gobiernos del PSOE, ya saben lo que tienen que hacer» 213 .

Al amiguismo y corrupción praticados desde las instituciones - cargos públicos del PNV habían utilizado la coalición para obtener el respaldo de destacados personajes de la vida cultural, política y deportiva ${ }^{214}$ - y para las instituciones - la afiliación al PNV se habría convertido en el principal aval para entrar en las instituciones vascas ${ }^{215}$ - se unía lo que Garaikoetxea calificó de riesgo de «fascismo blando», que consistía en un clima social de temor generalizado, creado por los militantes del PNV «en numerosas localidades de Euskadi, sobre todo en los pueblos pequeños». Según esto, grupos de pequeños comerciantes, que no compartían sus ideas, estaban «siendo sometidos a un auténtico boicot por aquellos que, sólo por el hecho de tener un carné, utilizaban su capacidad intimidatoria. Cuando hablo de los que tienen un carné, me refiero al carné del PNV. A nosotros nos ha llegado una lluvia de quejas de gente que se siente afectada, intimidada. Y más concreto no puedo ser, porque si se sabe quiénes son los señores en cuestión, pues tienen que emigrar». El resultado final de estas prácticas era «una tela de araña asfixiante, que puede llegar a desembocar en una especie de fascismo blando» ${ }^{216}$, en una sociedad en la que se aniquilaba al disidente.

213 Correo 21, 28. Ver, también, El País 21, 20. Refiriéndose al voto útil solicitado por el PNV y PSE, Jasone Irarragori dijo: «Este voto es el que permite seguir como hasta ahora, la mayoría que evita investigar los casos de corrupción, el que posibilita, en definitiva, poner en práctica la política del rodillo» (Correo 21, 28). Garaikoetxea repitió en Correo 22, 26 la idea de que votar al PNV era asegurar «la presencia del PSOE, perdón del PSE-EE en el Ejecutivo de Vitoria... Los ciudadanos nacionalistas que apuestan por esa opción ya saben lo que les espera, que consejerías tan importantes como la de Educación, Urbanismo o Trabajo sean dirigidas por socialistas».

214 Ver Correo 22, 26, donde también se dice: «Cargos políticos que desde hace varios meses han empleado su tiempo, el tiempo que tendrían que haber dedicado a la Diputación de Guipúzcoa para servir a todos los ciudadanos, a (sic) ir a pescar a las aguas de otros partidos. Han empleado la fuerza de las subvenciones, el poder que otorga suministrar los bienes y servicios a su antojo y hasta las aspiraciones de alguno por ocupar un cargo público, para "seducir", para presionar con tan importantes argumentos». Denuncias de amiguismo y corrupción en Deia 12, 10; Deia 13, 4; Correo 15, 25; Correo 17, 19; Deia 17, 10; Deia 18, 6; Correo 19, 17; Correo 21, 28; Correo 22, 26. En Correo 14, 24, Jasone Irarragorri dice: «No puedo estar de acuerdo con la cantidad de enchufados y cargos de confianza de nuestras instituciones, aunque sean nacionalistas, ni puede dejar de sonrojarme la financiación irregular de los partidos, aunque sean nacionalistas».

215 Ver Correo 15, 25. También, Deia 17, 10.

216 Correo 15, 25. En Deia 13, 4, se habla de la corrupción como de una «violencia blanca incruenta, pero que ejerce presión y supone un fascismo blando al boicotear socialmente a quien no posee un carnet de un partido determinado». En Deia 17, 10, se dice que el resultado de los métodos violentos del nacionalismo radical y de las prácticas de corrupción y amiguismo (se entiende, del PNV) es «una sociedad atemorizada por las pistolas y por el abuso de poder, que aniquila al que piensa de manera diferente». 
En buena medida la crítica al PNV se centró en la persona de Arzalluz — también se censuró la indiscreción de Ardanza ${ }^{217}$ - de quien, para empezar, se dijo que no era nacionalista. «Dijo (Arzalluz), y hace falta morro, que si renunciamos a la autodeterminación dejamos de ser vascos y nacionalistas, cuando él fue quien expulsó del Gobierno vasco a Oliveri, Gallastegi y Javier Caño por defender este derecho. La sentencia, pues, la ha dictado el propio señor Arzalluz: según su juicio él no es ni vasco ni nacionalista. Para EA, en cambio, es vasco, porque no todos los vascos piensan igual, pero no es nacionalista» 218 .

$\mathrm{Su}$ radicalismo verbal, tanto en períodos electorales como fuera de ellos, criminalizaba el nacionalismo y crispaba el ambiente de tal manera que impedía el «debate de los problemas pendientes del Estado», es decir, el debate nacionalista. Para Pilar Rahola, de ERC, «cada vez que Arzalluz utiliza la radicalidad verbal, tenemos que dar muchas explicaciones y hacer mucha pedagogía nacionalista. Es más, en Cataluña solemos decir: cada vez que este señor la suelta, con perdón, los catalanes recibimos un palo» ${ }^{219}$. Por otra parte, sus manifestaciones «entre el insulto y el sustrato racista» y sus «barbaridades», «que descalifican por completo a un político», habían sustituido la rendición de cuentas debida a los ciudadanos de la gestión nacionalista de Gobierno, además de ensombrecer y desacreditar la imagen del nacionalismo vasco, del Gobierno y de la Lehendakaritza. Arzalluz, por otra parte, habría «suplantado y reducido al silencio» a Ardanza durante la campaña, afirmación que no se corresponde con los datos manejados en este trabajo, para ocultar la responsabilidad en el Gobierno de coalición ${ }^{220}$. «Todavía mantengo la esperanza dijo Garaikoetxea refiriéndose esta vez a distintos oradores del PNV - de que otros hablen, como ya hemos hecho nosotros del problema de las minusvalías físicas o de los problemas económicos e industriales del país, en vez de hablar de blancos, de negros, de carteristas, de historias que no interesan a nadie y sólo pueden tener morbo en términos tristemente humorísticos» ${ }^{221}$.

Todas las críticas dirigidas contra el Partido Nacionalista por su gestión de Gobierno se hicieron extensivas al Partido Socialista por su parti-

217 Ver Correo 20, 32.

218 Palabras de Garaikoetxea en Correo 17, 19. Ver, también, Deia 17, 10.

219 Correo 19, 17.

220 Correo 22, 26.

221 Correo 21, 28. Más críticas en Correo 8, 15; Correo 9, 32; Deia 9, 7; Correo 12, 19, por la marginación de la mujer; Correo 13, 25; Deia 16, 14, por no apoyar la entrega del $0,7 \%$ para el tercer mundo. 
cipación en el mismo. De ahí que, cuando los socialistas alabaron su coalición con los nacionalistas, Oliveri manifestara que no sabía de qué país hablaban, ya que por lo que hacía al País Vasco, éste no había resuelto la pacificación ni la normalización, tenía el Estatuto absolutamente paralizado, seguía con las transferencias importantes pendientes y había batido el récord de parados 222 . Aparte de esto, hubo palabras duras contra el uso meramente electoralista del «espíritu de Anoeta», contra la presencia de los dirigentes nacionales de los Partidos, contra el enchufismo practicado en el caso de Osakidetza y, especialmente, contra la imagen vasquista que pretendían dar los socialistas y que no respondía a lo que practicaban desde las instituciones, por lo que la coalición con ellos solos era contraria a los postulados nacionalistas ${ }^{223}$.

Sobre la posibilidad de que fuese a la oposición, Garaikoetxea manifestó: «No me lo creo. El PSE-EE ha demostrado en los últimos ocho años que es capaz de aguantar hasta aceite hirviendo antes de dejar las sillas de Ajuria Enea» ${ }^{224}$.

El Partido Popular no disputaba a EA su espacio electoral ni había participado en las tareas de Gobierno. Por ello lo que se dijo sobre él fue poco y suave e, incluso, amable. La presencia de Aznar y la de los líderes de los demás Partidos de ámbito estatal recibió el mismo comentario: «Cuando pasen las elecciones se marcharán y tendrán puestos sus corazones en otros pueblos y en otras gentes. Nosotros les escuchamos y los recibimos bien, porque este pueblo tiene fama de recibir bien a sus visitantes, pero lo mismo que escucharíamos a un alemán o a un inglés»225.

Su campaña no se orientaba al Parlamento Vasco, sino a la Moncloa, $\mathrm{y}$, al igual que los socialistas, fue criticado por «utilizar hoteles de lujo, deportistas, tránsfugas y algún que otro charlatán de feria» para solicitar el voto 226 . Contrario al traspaso de la Mesa de Ajuria Enea al Parlamento, parecía, en opinión de Garaikoetxea, que no se opondría a un nuevo consenso, aunque estuviera presente Herri Batasuna ${ }^{227}$.

222 Ver Correo 12, 19.

223 Ver: Correo 8, 15; Correo 9, 32; Correo 11, 25; Correo 12, 19; Deia 13, 4; Correo 15, 25; Correo 16, 34; Deia 16, 14; Correo 17, 19; Deia 18, 6; Correo 21, 28; Correo 22, 26.

224 El Mundo del País Vasco 18, 12.

225 Correo 9, 32, palabras de Jasone Iraragorri.

226 Correo 17, 19.

227 Ver Correo 11, 25 y Correo 18, 24, donde a la pregunta del periodista de si «puede dejarse fuera de ese nuevo foro al PP si continúa empeñado en rechazar el diálogo con $\mathrm{HB}$ » respondió Garaikoetxea diciendo: «No creo que el PP sea tan "feroche". Hay algo de pose electoral, dicho sea con todos los respetos. Si se hacen las cosas razonablemente, el PP no se descolgará». 
También se habló muy poco de Herri Batasuna y, esencialmente, lo poco que se dijo fue para marcar la diferencia y distancia entre HB y Eusko Alkartasuna, es decir, para definir por vía de rechazo al propio Partido. Si EA, entre otros datos, se diferenciaba del PNV por su nacionalismo versus regionalismo y por la honradez frente a la corrupción, de Herri Batasuna la diferenciaba el tener «limpias las manos de la violencia terrorista». Todo esto ya está recogido en el trabajo. Baste recordar ahora que bajo nombres distintos, HB, nacionalismo radical o violencia terrorista, se calificó a Herri Batasuna de practicar un nacionalismo de guerra de guerrillas, un radicalismo asilvestrado y un infantilismo revolucionario, que confundía «el progreso con la quema de autobuses, con la algarada callejera y los tiragomas» 228 . Esta y otras violencias más graves, además de las prácticas de corrupción y amiguismo del PNV, eran, como se ha indicado, las que hacían de la sociedad vasca «una sociedad atemorizada por las pistolas y por el abuso de poder, que aniquila al que piensa de manera diferente»229. ETA, por otra parte, estaba «tiñendo de descrédito la causa vasca ${ }^{230}$.

Poquísima atención la que se prestó a Unidad Alavesa, pero se alzó la voz para denunciar que en su seno existiesen personas inmigrantes, que eran las que más arremetían contra el euskera. En tácita referencia a Pablo Mosquera, se le recordó el derecho constitucional vigente en Estados Unidos de América, que prohibía presentarse a la elección a Presidente a toda persona, que no hubiese nacido en el país. "Según nuestra normativa de autogobierno - dijo Garaikoetxea - el señor que viene de Lugo o de donde sea, se inscribe en el censo de Andoain, Donostia o Bilbao y al día siguiente es candidato a lehendakari; pero, por favor, que no sea el que arremeta más contra el euskera y la supuesta discriminación del castellano en su pueblo de acogida» 231 .

228 Correo 17, 19. Esta identificación resulta sumamente benévola, aunque no parece que se dijera con sentido excluyente.

229 Deia 17, 10. Ver, además de los lugares ya citados sobre diferencias entre EA y HB y PNV, Correo 14, 24; Correo 17, 10; Deia 17, 10; Correo 18, 24.

230 El Mundo del País Vasco 8, 9.

231 Correo 19, 17. En Egin, además de los lugares citados, se pueden consultar para la campaña de EA los siguientes textos, que no añaden nada nuevo a lo recogido en este trabajo: 8,$11 ; 9,13 ; 9,18$ (entrevista a Jasone Iraragorri sobre el siguiente Gobierno); 10, 16 (derecho de autodeterminación y rechazo de la violencia); 11, 9 (crítica al PNV y PSE-EE); 12, 14 (despropósito de un Gobierno monocolor); 13, 15 (corrupción y crisis económica); 14, 11 (servicios sociales); 15, 10 y 11 (entrevista a Carlos Garaikoetxea: violencia y diálogo institucional sin exclusión de HB; respeto absoluto a la voluntad mayoritaria de la comunidad vasca, mientras no se dé un consenso mayoritario distinto; necesidad de una tregua de ETA; prioridad de los derechos humanos; rechazo de toda política que agrave innecesariamente la 


\section{LA CAMPANA DE HERRI BATASUNA}

\section{Datos básicos}

Las diferencias cuantitativas de información, un $8 \%$ menos que Eusko Alkartasuna y un 25\% menos que el Partido Nacionalista Vasco, no afectan a la campaña de Herri Batasuna desde el punto de vista cualitativo ${ }^{232}$. Esta orientó su atención en un $60,42 \%$ a transmitir su imagen de coalición nacionalista y en un 39,57\% a la crítica de los Partidos Políticos.

La definición ideológica de HB presenta una dificultad metodológica, ya que el esquema seguido en éste y otros trabajos, que distingue entre nacionalismo, cuestiones programáticas no nacionalistas y Gobierno, se altera por el carácter totalizador que se da al concepto de nacionalismo. Según esto, no hay criterio ni concepto sobre nada más allá del nacionalista. El nacionalismo es la meta y el nacionalismo es la solución real de los problemas. Como éste es una cuestión fáctica, nada hay que decir hasta que se realice. Según esto, cualquier cuestión tratada en la campaña es nacionalismo, bien porque lo sea y se presente como un objetivo a realizar, o bien porque represente un problema, v.g. la crisis económica o la violencia, que es interpretado como consecuencia de la ausencia de nacionalismo, cuya solución se encomienda a la realización previa de las tesis nacionalistas. De todos modos, se habló en la campaña de cuestiones no nacionalistas, que las estructuramos de acuerdo con el método utilizado hasta ahora, aunque en boca de los presentadores tenían un sentido exclusivamente nacionalista. Se hace esta advertencia no sólo por razones metodológicas, sino para evitar la confusión que resultaría de concluir que HB dio más importancia a materias no nacionalistas que a las estrictamente nacionalistas.

situación de los presos, familiares y entorno social; gobierno de construcción nacional); 15, 16 (gobierno multipartito y temor social); 16, 15 (rechazo del aislamiento de HB y necesidad de un acuerdo social); 17, 10 (diálogo para la paz, autodeterminación y crítica del PNV); 18, 15 (corrupción); 19, 13 (agotamiento del modelo autonómico); 20, 11 (identificación del voto al PNV con el voto al PSE-EE); 22, 13 (nacionalismo y progreso). Se puede consultar, asimismo, El País 18, 16 (Mesa de Ajuria Enea y Herri Batasuna). De El Mundo del País Vasco ver: 9, 14 (PNV y PSE-EE, responsables del bloqueo del autogobierno y Gobierno españolista; pacto económico y social y crítica al gigantismo de la Administración vasca); 10, 16; 11, 10; 12 , 6 y 11; 13, 7; 14, 10; 15, 10; 16, 14; 17, 19; 18, 10 (entrevista a Carlos Garaikoetxea: Oposición y crítica al partido gobernante; nacionalismo y progresismo; Ardanza, oscurecido por Arzalluz; pretensiones hegemónicas políticas y sociales del PNV; corrupción y miedo social; sentimientos nacionalistas enfrentados; necesidad de que HB negocie; terrorismo de Estado; Gobierno tripartito); 19, 17; 20, 13; 21, 6 y 14; 22, 12.

232 Esto se comprueba comparando la información de El Correo, tomado como unidad base de medición, con la de los demás periódicos, especialmente, con la de Egin. 
La imagen de la coalición se forjó con un 43,83\% de nacionalismo (30,55\% del total de la campaña) en sentido estricto, recurriendo a los conceptos de libertad nacional, soberanía, oposición España-Euskadi, autodeterminación, Estatuto, reconstrución nacional y derechos del pueblo vasco. El 49,57\% (34,55\% de la campaña) se basó en los temas de la violencia, pacificación, negociación, abstención, problemas cotidianos, crisis económica, capitalismo, críticas a la corrupción y a los medios de comunicación. En cuestiones de Gobierno se ha incluido la participación en las instituciones políticas, aunque bien podía ir esta materia en el apartado segundo, que alcanzó un 6,55\% de la imagen ${ }^{233}$.

La crítica de los Partidos Políticos se distribuyó de la siguiente manera: el 39,56\% (15,65\% de la campaña) fue dirigido contra todos los Partidos Políticos sin distinción, en cuanto fundamento de un sistema político rechazado por la coalición; el 39,35\% (15,57\% de la campaña), contra el PNV y, en cierta medida, también contra el Partido Socialista por su coalición en la anterior legislatura; el 9,89\% (3,91\% de la campaña) contra Izquierda Unida; el resto, cantidades inapreciables, contra Unidad Alavesa, Partido Popular y Eusko Alkartasuna.

La máxima participación correspondió a K. Landa con el 37\%, seguido de Idígoras con el 12,38\%, I. Aizpurua con el 10,31\%, Iruin con el $9,3 \%$, J.M. Olarra, también, con el 9,3\% y otros presentadores con participaciones inferiores, destacando la ínfima participación de T. Erkizia y Aoiz.

\section{Desarrollo de la campaña}

\section{A) La definición ideológica}

\section{El nacionalismo de Herri Batasuna}

Las dos cuestiones más repetidas fueron la autodeterminación y la necesidad de la reconstrucción nacional, que, juntamente con la paz, formaban un tríptico inseparable. «Estos tres elementos van necesariamente unidos. Cualquier intento de defenderlos por separado está abocado al fracaso y a la prolongación del conflicto» ${ }^{234}$. Así se expresó Idígoras nada más comenzar la campaña. La autodeterminación constituía el derecho más fundamental de Euskadi y, mientras no fuese reconocido, el

233 El rechazo de la abstención, dado que no tiene por objetivo el fortalecimiento del sistema político, sino mostrar la fuerza del nacionalismo radical, podía incluirse en el primer apartado, tal como se ha hecho en alguna otra ocasión.

234 Correo 9, 29. Ver también, Deia 9, 9. 
«conflicto vasco» se prolongaría eternamente. El punto de partida, pues, de toda la argumentación era la situación de Euskadi, interpretada como un «conflicto» con el Estado español235, y su solución pasaba por el reconocimiento de tal derecho ${ }^{236}$. La Constitución española, impuesta «con un ejército», negaba la autodeterminación, es decir, el verdadero pilar y fundamento de la democracia. «No habrá democracia en Euskadi - declaró el más activo de los propagandistas de HB- mientras no se reconozcan los derechos básicos» ${ }^{237}$, entre los que destacaba el de autodeterminación.

Cualquier ocasión o problema fue bueno para legitimar la autodeterminación. Así, por ejemplo, la cuestión de las volantas, que afectaba a los pescadores, permitió al orador de turno justificar el derecho de los mismos a defender la autodeterminación como objetivo primordial de su lucha 238 .

En Herri Batasuna no queda duda de que la autodeterminación era algo distinto a un derecho de la nación que debía ser utilizado democráticamente por los nacionales para la libertad y soberanía de Euskadi, cuyo resultado debería ser respetado. En este concepto de autodeterminación las voluntades nacionales individuales serían el sujeto decisorio. Este es el concepto de autodeterminación, que defendió en la campaña Eusko Alkartasuna, pero no Herri Batasuna. Esta identificó el derecho de autodeterminación con el derecho de la nación a que nada ni nadie impidiese

235 En Deia 12, 8, Alvaro Reizabal defiende que el «enfrentamiento que vive Euskadi con el Estado español» es la causa del origen y de la persistencia de la violencia. En Egin 15, 14 , Idígoras afirma: «Aquí existe un conflicto político con el Estado, cuya solución, única y exclusivamente ha de ser política, sin exclusión y con la aportación de todos, pero respondiendo a unas coordenadas donde la libertad nacional y social tengan la prioridad que se merecen».

236 «Tenemos que ser valientes - dijo Idígoras - a la hora de decir que una salida política tiene que estar en consonancia con el derecho más importante reconocido por todos, como es el derecho de autodeterminación» (El Mundo del País Vasco 9, 17). «...Necesitamos soluciones en Euskadi - declaró Landa - y para eso es necesario un acuerdo basado en reconocer que aquí el conflicto es político. Que se nos deje ya de hablar en términos de delincuencia común, de terrorismo y de historias, ese es un discurso manido, absolutamente reaccionario, en el que hacen tabla común desde el PP y UA hasta IU...» (El Mundo del País Vasco 19, 10).

237 Correo 19, 27. El texto completo dice: «Aquí vale muy poco ser partidario de la autodeterminación, porque tenemos una Constitución que nos imponen con un ejército. $\mathrm{O}$ se da a la población la posibilidad de optar o se hace trampa. No vale decir "ustedes pueden hablar de independencia", si luego se nos niega la vía política para acceder a ella con la amenaza del ejército. No habrá democracia en Euskadi mientras no se reconozcan los derechos básicos».

238 Correo 14, 25. En Correo 11, 25, se defiende que el problema pesquero es consecuencia de la falta de capacidad de decisión, ya que ésta o éstas se toman en Vitoria, Madrid o Estrasburgo, lo que da a entender que o bien la oradora ha sufrido una acumulación de capitales o bien pensaba en una especie de democracia directa de los grupos de interés. Sobre la autodeterminación ver, además, Correo 8, 23; 11, 25; 12, 17; 21, 20; Deia 12, 8. 
el desarrollo natural, objetivo y necesario hacia la soberanía del Estado nacional. Si bien este proceso no se puede realizar sin conciencia nacional, ésta no se refiere a la universalidad de las conciencias individuales, sino a aquéllas, todas o pocas, que sean necesarias o convenientes para realizar el objetivo nacional. Este concepto de autodeterminación alimenta esencialmente el planteamiento mesiánico, heroico y salvador de los «conscientes», que se autodefinen como los salvadores de la patria y del ser nacional. La autodeterminación, así entendida, incluía la unidad territorial e institucional de la misma ${ }^{239}$, integrando todos ellos los derechos fundamentales colectivos de los vascos 240 .

Después de 16 años de existencia de HB, la soberanía seguía siendo una aspiración, no una realidad, que justificaba la validez del compromiso inicial de luchar por ella, según aseguraba uno de sus cofundadores, Idígoras 241 .

Todo lo dicho hasta ahora desde la autodeterminación hasta la soberanía se legitimaba con el proyecto de construir la nación vasca o, más simplemente, se identificaba como partes del proceso de construcción. «La independencia — manifestó Landa - es una condición necesaria para poder realizar la construcción nacional de Euskadi» ${ }^{242}$. En cualquier

${ }^{239}$ La unidad territorial era otro de los derechos básicos de Euskadi. Ver Correo 8, 23; 11, 25; 12, 17; 20, 26. Egin 20, 12. En Correo 20, 26, Aoiz defiende la unidad territorial de Euskal Herria para «construir desde ya la nación vasca». En Deia 15, 8, Landa afirma que HB jamás aceptará la división de Euskal Herria ni «la ruptura de soberanía que supone el Parlamento de Gazteiz». Ver, también, El Mundo del País Vasco 13, 6 y 19, 11 (declaraciones de Karmelo Landa).

${ }^{240}$ Los insumisos y objetores constituían una prueba de «que los ejércitos no pueden inculcar los derechos de un pueblo». Aquí, como en el caso de la autodeterminación, cualquier problema era manifestación del nacionalismo, que, a su vez, constituía su solución.

241 Correo 19, 24 y Deia 19, 6. Ver también, Correo 21, 20 y El Mundo del País Vasco $12,9$.

242 El Mundo del País Vasco 19, 10. Las manifestaciones completas de Landa sobre la independencia fueron: «HB está planteando el establecimiento de un marco democrático vasco. La izquierda abertzale tiene su modelo, que es la independencia para Euskal Herria. La independencia es una condición necesaria para poder realizar la construcción nacional de Euskadi. Lo que no hacemos es predeterminar situaciones: vamos a imponer el Estado de las autonomías o el federalismo y luego ya hablaremos de autodeterminación. Eso es jugar con trampa. A los vascos no se nos está reconociendo la unidad de la nación vasca y se nos amenaza incluso con una intervención armada desde la Constitución. Estamos convencidos que la mejor opción para la población vasca es una opción de izquierdea y abertzale. Queremos un juego limpio, democrático y sin exclusiones. En ese juego vamos a proponer una Euskal Herria independiente, que posibilite la cohesión de nuestra nación, una construcción nacional y social que permita terminar con esta desigualdad social brutal, que dé lugar a una izquierda hegemónica que lleve a su sitio a esa derecha vasca que se está envalentonando, el PNV, y que podamos construir un País Vasco progresista, solidario, con una identidad garantizada y viviendo en Europa. Este es nuestro modelo y no vamos a agachar la cabeza ante posiciones 
caso, la voluntad de crear una nación quedó manifestada en muchas ocasiones $^{243}$, desde la afirmación de I. Aizpurua de que «en Herri Batasuna queremos construir un pueblo y no caer en el enfrentamiento civil» 244 hasta la de Iñigo Iruin de que en el camino hacia la soberanía «no basta con resistir; la construcción nacional exige demostrar que hay una alternativa real a la situación económica y voluntad de converger con sectores del abertzalismo y la izquierda» 245 .

Para el final de campaña se dejó el anuncio de que «estamos asistiendo al nacimiento político de la nación vasca, que será una joven nación si nosotros lo decidimos así...; el pueblo vasco es progresista y Euskal Herria va a nacer al mundo. Será una nación libre y solidaria...; falta el impulso, la determinación de hacer el camino y superar todos los obstáculos...; los vascos conseguiremos lo que otros pueblos, otras naciones ya han conseguido»246. A pesar de la oposición de otros Partidos y de los grupos de poder, el proceso que conducía al nacimiento de la nación vasca era imparable 247 .

Tal nacimiento era incompatible con el sistema político vigente $\mathrm{y}$, en concreto, con el Estatuto de Autonomía, caracterizado por su imposición ajena a la voluntad de los vascos y por sus efectos nocivos para Euskadi. De ahí la necesidad de un nuevo marco político ${ }^{248}$.

antidemocráticas, como otras fuerzas políticas, que incluso están intentando buscar terceras vías como Estados federales. No, nosotros no vamos a aceptar terceras vías si pasan por amputar derechos democráticos básicos».

243 Ver, además de otros lugares citados, El Mundo del País Vasco 20, 9 y Egin 21, 20.

244 Correo 11, 25, donde también aparece la frase mítica de «defender la casa del padre» como objetivo de HB.

245 Correo 19, 24. Ver también, Correo 9, 29; 11, 25; 12, 17; 21, 20.

246 Deia 22, 9. Ver tambien, Egin 22, 11 y El Mundo del País Vasco 22, 9. En Correo 21, 20, la información se refiere a un acto distinto en el que el mismo protagonista, Karmelo Landa, anuncia que «el mundo está asistiendo al nacimiento de la nación vasca» y también que Euskadi vive «un momento histórico, porque estamos asistiendo al nacimiento de una nación». Como puede verse, en este texto se habla simplemente de nación, mientras que en el anterior se habla de nación política, que no es lo mismo. La correcta utilización de ambos términos habría dado al mitinero la posibilidad de crear un discurso más lógico desde el punto de vista argumental, deficiencia que se observa no sólo en este caso, sino en toda la campaña.

247 Ver Correo 21, 20.

248 Ver Correo 9, 29; 11, 25; 16, 28; 19, 26. En Correo 14, 25, se afirma que el Ejecutivo vasco era el responsable de los problemas económicos de Euskadi y que la solución estaba en un cambio en las relaciones entre el País Vasco y la Administración central, previa renuncia al Estatuto de Gernika, en el cual «ni siquiera nuestros gobernantes creen». En Correo 12, 17, se dice: «Porque somos euskaldunes y no queremos ser un trozo más de España, no nos contentamos con el Estatuto, ni hemos abandonado el ansia de independencia». Lo mismo en Egin 12, 11. 


\section{Cuestiones programáticas}

Una vez definido el problema de Euskadi como un problema nacional, como la contradicción fundamental vivida por el pueblo vasco, se deduce que la solución a cualquier cuestión exige previamente la libertad o soberanía nacional. Esto se predica constantemente de todo y, en primer lugar, del problema de la pacificación de Euskadi.

A este respecto, Herri Batasuna fue presentada como una «formación política implicada en lograr la paz». «Somos los primeros —añadió Reizabal - interesados en conseguirla, porque la izquierda abertzale es una víctima directa de muchos de los sufrimentos que nuestro pueblo ha vivido en las últimas décadas» ${ }^{249}$.

Pero la paz no consistía en la desaparición de las formas violentas, sino en el «establecimiento de las condiciones democráticas para un proceso de normalización democrática de Euskadi» 250 , porque era el «déficit democrático» que vivía el pueblo vasco el origen, precisamente, de la violencia, y su persistencia obedecía a que nadie apostaba «con sinceridad por la superación del enfrentamiento que (vivía) Euskadi con el Estado español» 251.

La paz, según la intervención de Reizabal, que durante décadas se había negado al pueblo vasco, como se le había negado el derecho democrático a elegir su destino mediante el derecho de autodeterminación, era «un concepto ligado al respeto de las libertades individuales y colectivas. El respeto a los derechos humanos y a los derechos de los pueblos (era) la base de la paz y de toda legitimidad democrática» 252 .

La violencia era «un instrumento político en la lucha por la soberanía de nuestro pueblo» y su solución no dependía de la desaparición de los que la utilizaban, sino de «la superación de la imposición (y de) la resolución política del conflicto» 253 .

El camino inmediato era el diálogo y la negociación política ${ }^{254}$, donde se planteaba la cuestión de los sujetos, que tenían que dialogar. En los

249 Deia 12, 8. En Correo 12, 17, se interpreta la lucha de los presos como lucha por la paz, por la autodeterminación y unidad territorial.

250 Ibidem.

251 Ibidem.

252 Ibidem. En Deia 13, 4, K. Landa afirma que la paz es «un derecho a la autodeterminación del pueblo vasco, un reconocimiento de la unidad de Euskal Herria, es terminar con la militarización y la imposición y sustituirlas por los derechos democráticos básicos». En Correo 8, 23, se dice: «La paz tiene unos contenidos políticos relacionados con los derechos de Euskadi como nación». El rechazo del derecho de los presos a la reinserción era la defensa de «sus derechos individuales y colectivos» (El Mundo del País Vasco 19, 11).

253 Ibidem.

254 En varias ocasiones se puso como ejemplo la experiencia positiva irlandesa. Ver Correo 19,$27 ; 22,28$. 
primeros días de campaña se llamó a los Partidos Políticos a que hablasen con Herri Batasuna sobre la paz. Se pedía a los Partidos Políticos la misma actitud que ofrecía Herri Batasuna, un claro esfuerzo por la distensión, por la superación de los atrincheramientos y, en definitiva, por el diálogo sobre el tema ${ }^{255}$. En este sentido, Iñigo Iruin insistió en que HB daría todos los pasos necesarios para hablar con las formaciones políticas vascas, añadiendo que el diálogo era «innegociable» y debía ser «incondicional» en el sentido de que nadie estaba autorizado a establecer condiciones previas - ni siquiera la suspensión de los atentados, como diría más tarde K. Landa 256 -, al hipotético inicio de las negociaciones. No obstante, el mismo orador clarificó qué «condición» no se incluía en su concepto de lo «incondicional» al decir: «Todos nos tenemos que mover en la búsqueda de la paz, incluidos nosotros. Pero que quede claro que la paz se llama autodeterminación» 257 .

Lo que cierto sector de la prensa interpretó como una nueva estrategia radical, que consistiría en la potenciación del papel de los Partidos Políticos y de los grupos sociales en la construcción de la paz, por un lado, y, por otro, en la marginación de ETA, se desvaneció, cuando Olarra afirmó que «si el Estado quiere la paz, ahí está Santo Domingo»258. Los llamados a dialogar y negociar eran el Estado y ETA.

Aunque todavía en el acto político, que siguió a la «Marcha por las libertades democráticas», el comunicado oficial de la Mesa Nacional habló de proponer el inicio de negociaciones y reclamó «un acuerdo social amplio» sobre el carácter político del enfrentamiento entre el Estado y Euskal Herria, ya no quedó ninguna duda sobre la cuestión. Los Partidos políticos tendrían una función distinta de la que correspondía a los verdaderos protagonistas, ETA y el Estado. Según la Mesa Nacional, a los Partidos les correspondía abandonar «los pactos de Madrid, Iruña y Ajuria Enea, para así poder abordar la vía de una negociación política integral, sin exclusiones, que procure un nuevo marco basado en el reconocimiento de los derechos democráticos básicos para la paz» ${ }^{259}$.

Si bien el aspecto negativo del papel de los Partidos fue claramente definido, no ocurrió lo mismo con su función positiva. «En la medida que ETA — declaró K. Landa en los últimos días de campaña- entre a

255 Ver Correo 9, 29; 10, 17; Deia 9, 9. En El Mundo del País Vasco 10, 7 Idígoras dice: «Hay que huir de atrincheramientos».

256 Correo 19, 27.

257 Correo 10, 17. La misma exigencia aparece en Correo 22, 28. En Egin 10, 12, se dice: «La paz en Euskal Herria se llama autodeterminación». Egin 10, 12, contiene la más amplia información de Iñigo Iruin sobre el tema.

258 Correo 12, 17.

259 Deia 13, 4. Ver Correo 13, 25 y El Mundo del País Vasco 19, 10 y 11. 
negociar con el Gobierno español y que, además, se dé una negociación entre las fuerzas políticas y sociales, ETA no será un obstáculo» ${ }^{260}$. La puerta de la paz, insistió, estaba en Santo Domingo, y, si el Gobierno español quería iniciar «parte de esa negociacion», debía llamar a Santo Domingo. Su afirmación de que «ETA y el Gobierno tienen un lugar y los partidos tenemos otro» no se aclaró261. Sí se aclaró el contenido que tenía la atribución a la voluntad popular del papel decisivo en el proceso de negociación. Sobre esta cuestión Landa afirmó: «La voluntad popular debe ser quien decida. Nosotros estamos reivindicando un marco democrático y en ese marco lo definitorio tiene que ser la voluntad popular, sin ingerencias y sin exclusiones. Eso es la clave, no hay solución sin eso» ${ }^{262}$. Esto quería decir que la voluntad popular sólo sería operativa a partir del momento en que se produjera el objetivo fundamental de Herri Batasuna, el cambio del marco político, es decir, la realización de la libertad y de la soberanía. Antes de esto, no existían las condiciones para el ejercicio democrático de la voluntad popular.

La campaña de Herri Batasuna pretendió responder a la acusación tantas veces repetida de que, centrada sobre la libertad y soberanía nacional, se olvidaba de los problemas diarios de los vascos. Así, aquélla comenzó con la proclamación de que «la creación de empleo, la política social y la lucha contra la marginación son los ejes de intervención de total prioridad en la acción política de $\mathrm{HB} »^{263}$. En consecuencia, se mencionaron el paro, el fraude fiscal, la vivienda, el nuevo capitalismo salvaje, la crisis económica, el problema pesquero, la cuestión de las volantas, el desmantelamiento industrial, la división entre trabajadores y parados, los nuevos contratos laborales, el riesgo del despido libre, la corrupción, la marginación, los problemas concretos de la siderurgia integral, de los aceros especiales, de la construcción naval, papeleras, baserritarras, arrantzales, ecologismo y feminismo problemas todos ellos de los que se

260 Correo 19, 26.

261 Correo 19, 27. En Deia 15, 8, K. Landa repite en una entrevista que «está muy claro que el marco (se refiere al nuevo marco político del que HB habló continuamente) tiene que salir de una negociación política entre ETA y el Gobierno. Y entre las fuerzas políticas vascas tiene que haber también un proceso de acuerdos políticos. Incluso entre las fuerzas sociales. Ese es un diseño de negociación integral sin exclusiones». La misma tesis se repite en la entrevista, sin ningún tipo de clarificación. En la entrevista se recurre ampliamente al proceso iniciado con el problema de Irlanda del Norte, que se presenta como modelo a seguir, y que se interpreta como un proceso de acuerdos políticos que parten del «reconocimiento de los derechos de autodeteminación y unidad territorial». En El Mundo del País Vasco 19, 11 aparece la misma idea.

262 Deia $15,8$.

263 Egin 9, 15. 
hacía responsables a la Administración central, al Gobierno Vasco, a las multinacionales, al Fondo Monetario Internacional, al Banco Mundial, a los Partidos Políticos y al sistema político en general. Para todos ellos Herri Batasuna poseía soluciones que no desveló, a excepción de ciertas propuestas generales y, especialmente, a excepción de la ya conocida tesis de que en rigor de verdad tales problemas demandaban «un cambio profundo en las relaciones que mantenemos con Madrid»264 o «alternativas diferentes que pasen por un proyecto de construcción nacional y social; un proyecto abertzale y de izquierdas que responda a las necesidades de intereses de la mayoría social de nuestro pueblo»265. Herri Batasuna se consideraba la única depositaria de la tradición de la izquierda y de los nuevos valores obreros y progresistas ${ }^{266}$.

Herri Batasuna brindó más soluciones ante la crisis económica y social de Euskadi. Ya que ésta, en la que se incluían crisis sectoriales como la de la pesca o la de la agricultura, debía enmarcarse en el intento de «disolvernos en España y en un proyecto europeo al servicio de las multinacionales», Herri Batasuna propuso en varias ocasiones la «absoluta insumisión» a las medidas comunitarias que perjudicasen a los sectores indicados ${ }^{267}$.

El carácter utópico y propagandístico de las propuestas de HB era manifiesto en el caso de la normalización del euskera ${ }^{268}$. La simplificación de los problemas del paro y vivienda la concretó Idígoras en una frase lapidaria: «Aquí, sí hay dinero, lo que falta es honradez y dignidad» 269 .

El rechazo general del sistema político exigía la propuesta de otro nuevo. A semejanza de lo dicho en otras campañas, Herri Batasuna defendió la democracia participativa. Ya que el Parlamento Vasco, a modo

264 Correo 9, 29. Ver también, Correo 11, 25; 14, 25; 19, 26; 21, 20; Deia 21, 4. En Deia 11, 7, Karlos Rodríguez defendió el futuro del sector pesquero, advirtiendo que convenía «acabar con las artes depredadoras y declarar el Golfo de Bizkaia como zona sensible. Acabar con las importaciones masivas e invertir en los puertos pesqueros, así como mejorar las condiciones de trabajo para la juventud». Se trataba de propuestas ofrecidas por HB en su programa. En Correo 21, 20, Landa exige soluciones al desempleo y a las carencias básicas de la población, pidiendo solidaridad para superar la división entre trabajadores y parados. En Deia 14, 9, se propone incumplir la aportación del cupo al Estado.

265 Deia 11, 7. En Deia 15, 8, K. Landa habla de las 19 medidas concretas de HB contra el paro, aunque no menciona ninguna. Ver también, Egin 11, 13. En El Mundo del País Vasco 14, 13, Aizpurua dice: «HB es la llave para lograr la independencia y la justicia social».

266 Correo 18, 26.

267 Ver Correo 11, 25; Deia 11, 7; 14, 9.

268 Ver Deia 16, 13.

269 Correo 18, 26. Ver más intervenciones sobre el carácter social de HB en Egin 16, 14; 17, 8; 18, 17; 21, 10. Sobre la planificación global de las infraestructuras, ver Egin 20, 12. Sobre el «marco vasco de relaciones laborales», ver Egin 22, 12, entre otros lugares. 
de ejemplo, era una «caricatura» de lo que debía ser, el compromiso de HB consistía en «transformar el actual sistema político burocratizado y jerarquizado en un sistema de democracia participativa» 270 . Esta garantizaría que los organismos populares tuviesen «voz y derecho a expresar sus opiniones», de manera que la sociedad vasca asumiera un mayor protagonismo. Sólo HB defendía medidas «para que la ciudadanía (fuese) escuchada»271.

Supuesto el rechazo del sistema político vigente y la necesidad de una alternativa, las continuas llamadas a luchar contra la abstención no podían tener el sentido ordinario en cualquier Partido pro sistema. En el caso de un partido democrático, la llamada a la participación tiene dos vertientes: el apoyo al Partido en cuestión y el fortalecimiento del sistema político donde aquél actúa. En el caso de Herri Batasuna la petición del voto buscaba, por el contrario, únicamente demostrar la fortaleza del movimiento radical contra el sistema político y social instituido. La campaña comenzó con cierta desconfianza en el propio electorado. «Sé — dijo Idígorasque muchos compañeros están pensando en la abstención, pero deben saber que esa decisión sólo favorece a los gobernantes ${ }^{272}$.

Como parecía confirmarse la postura abstencionista, se produjeron varios cambios en la interpretación y valoración de la participación electoral. En primer lugar se la consideró de inferior importancia a otras participaciones. Así Olarra manifestó que la coalición ya había «demostrado su peso y su implantación en la calle, en la movilización, y eso es lo importante» 273 . En segundo lugar, se hacía responsable a la prensa de marginar a Herri Batasuna («tiranizar y practicar el apartheid con HB»), acusación que fue acompañada de graves amenazas contra los periodistas proferidas por Mikel Zubimendi: «Este es mensaje para los medios: que sepan que no aceptamos su actitud y que los periodistas no son intocables» ${ }^{274}$. Y en tercer lugar la explicación de que en las elecciones no se manifestara un resultado mayoritario a favor de Herri Batasuna radicaba en el «marco político», en la ausencia del derecho de autodeterminación,

270 Correo 16, 28. Karmelo Landa dijo que HB no reconocía a un Parlamento, que ni siquiera podía llamarse Parlamento Vasco. «Lo que hoy es el Parlamento Vasco — dijo- es una caricatura de lo que debe ser un Parlamento, porque no es depositario de la soberanía vasca, sólo recoge una parte del territorio y, lo que es más importante, está supeditado a la soberanía española» (Ibidem). Ver también, El Mundo del País Vasco 16, 15. Las mismas ideas en la entrevista de Deia $15,8$.

271 Ibidem. Ver, también Deia 16, 13.

272 Correo 9, 29.

273 Correo 12, 17.

274 Correo 15, 21. 
en la imposibilidad de que los vascos decidiesen libremente su forma política y en la ausencia de debates y verdaderos sondeos de opinión. Es decir, el sistema político y social vigente era el responsable de que al votar un electorado mayoritariamente nacionalista radical y de izquierda se produjera el sorprendente resultado de una victoria de la derecha vasca y española. Así lo expresó Karmelo Landa en una entrevista, respondiendo a la pregunta de si la abstención era el rival de HB: «El objetivo es movilizar al sector de izquierda abertzale, que es mayoritario. Se está produciendo una deformación de la realidad vasca, mediante la ausencia de debates y los sondeos de opinión, que pretenden sustituir lo que piensa la gente por muestras pequeñas e interpretadas de la opinión. Esto es muy grave, porque la voluntad mayoritaria de izquierdas está siendo ocultada y parece que la derecha, vasca o española, es hegemónica cuando la sociedad vasca es de izquierdas y abertzale... Aquí vivimos en un país mayoritariamente abertzale y de izquierdas y, sin embargo, lo que se refleja en unas elecciones es dos países fuertemente españolizados y muy de derechas. Hay algo que no casa. Se nos impone un marco político que da, como consecuencia, este reflejo». Ante la afirmación del entrevistador de que «igual lo que no concuerda es su afirmación de que la mayoría es de izquierdas y abertzale», Landa respondió: «Pero para ponerlo en tela de juicio son necesarios unos derechos básicos, el de la autodeterminación y que se nos deje a los vascos decidir sin injerencias la forma política que queremos... llegará el día en que podremos demostrar que la mayoría de la población es de izquierdas y abertzale... Aquí falta cultura democrática» 275 .

No obstante lo escrito, los argumentos esgrimidos para pedir el voto fueron la eficacia del movimiento radical demostrada en otras ocasiones (aquí se citaban cambios en el régimen franquista, paralización de la construcción de centrales nucleares o el desarrollo del euskera), la necesidad de frenar «a las fuerzas españolistas» que supondrían «la marginación y desprecio hacia Euskadi», una mayor participación en las instituciones para «luchar día a día por los problemas de la sociedad» y el reforzamiento del control de los Partidos gobernantes. Dirigiéndose a los que por motivos críticos habían negado el voto a HB en anteriores votaciones, Zubizarreta afirmó que la coalición no podía «desperdiciar ni un solo voto, por muy críticos que seamos con nosotros mismos» ${ }^{276}$.

«No podemos abstenernos» fue el grito final de la campaña. La resignación, la desesperanza y el silencio eran los principales enemigos de Herri Batasuna y los mejores aliados del PNV y Partido Socialista. La úl-

275 Correo 19, 26 y 27.

276 Correo 17, 29. Ver también, Deia 17, 7. Los mismos argumentos en Correo 22, 28 y en Deia 22, 9. Ver también, El Mundo del País Vasco 17, 12. 
tima argumentación para pedir el voto, repitiendo lo ya conocido, destacaba, en negativo, la pretendida identidad de HB, la lucha contra la derecha y el españolismo. "No vamos a consentir que se instalen sobre nosotros y hagan lo que están haciendo en nuestra sociedad» 277 . Antes se había dicho que una recuperación del voto de HB facilitaría el proceso de negociación y pacificación ${ }^{278}$.

\section{Cuestiones de Gobierno}

Como es de suponer, semejante cuestión no podía existir en el proyecto de Herri Batasuna, más que, en todo caso, como crítica, control o fiscalización de los Partidos en el poder. La promesa de mayor participación en el Parlamento, de mayor control de la actividad institucional, de defensa del programa político en las instituciones fue haciéndose más fuerte, hasta convertirse en un compromiso de participar activamente en el Parlamento, a medida que se acercaba el día de las votaciones. Su finalidad esencialmente electoralista parece lo más probable, aunque fuesen verdad las palabras de Tasio Erkizia de que HB iba a ser «látigo de los corruptos y oportunistas» para «limpiar las casas de los enchufados políticos», aplicando «el bisturí en todas las empresas públicas, ayuntamientos o instituciones en los que haya indicios de malversación de fondos públicos»279.

En resumen y en contra de lo que se dijo en la prensa y por la prensa, Herri Batasuna no había modificado su línea estratégica ni sus objetivos. Perseguía lo que antes había pretendido, sólo que «con mayor intensidad y enraizamiento en su base social de izquierda», según palabras de K. Landa ${ }^{280}$.

\section{B) Crítica de los Partidos Políticos}

Todos los Partidos Políticos firmantes del Pacto de Ajuria Enea ${ }^{281}$ fueron acusados de crear intolerancia social y de buscar la marginación política de HB con ocasión de la celebración de un debate entre los aspi-

277 Deia 22, 9 y Correo 22, 28.

278 Ver Deia 15, 8, donde Landa responde a la pregunta de «¿Qué puede aportar HB en este proceso?» de la siguiente manera: «Hablando en plata, una recuperación del voto ayudaría a acercar este proceso».

279 Correo 20, 26. Ver sobre esta cuestión: Correo 17, 29; 19, 26; 21, 20; 22, 28; Deia 21, 4. En Deia 16, 13, Landa afirma: «No vamos a dejar que nos cuelen más "chanchullos" como el de Osakidetza o el de las tragaperras y para ello vamos a hacerles un seguimiento cotidiano de toda la actividad institucional». En Deia 15, 8, se insiste en el seguimiento y control institucional.

280 El Mundo del País Vasco 19, 10.

281 El Pacto de Ajuria Enea fue definido por Iruin como «jaula de grillos donde sólo se defienden intereses partidistas» (Correo 10, 17). 
rantes a Lehendakari, al que no fue invitada Herri Batasuna. Tal hecho constituía una censura de las fuerzas políticas electorales ${ }^{282}$ y un acto de cobardía y de inmovilismo. La negativa de los Partidos a contrastar sus opiniones con HB probaba que no perseguían la paz. «No se puede hablar — dijo Idígoras - de diálogo y distensión, si a la vez se margina a la tercera fuerza política de Euskadi»283.

La respuesta de tales Partidos y del Gobierno a la disposición manifestada por ETA para buscar soluciones al problema de la violencia había sido de mayor represión, mostrando con ello la hipocresía y el cinismo con que se planteaban la pacificación. Especialmente los socialistas y, sobre todo, los del PNV habían prostituido los conceptos de «diálogo» y «negociación»284.

La reivindicación de los derechos democráticos y de la reconstrucción nacional diferenciaban a HB de todos los demás Partidos, y, si bien éstos podían tener planteamientos sociales distintos entre sí, sus proyectos para Euskadi eran idénticos: «Responden a un modelo españolista y defienden la patria común de los españoles»285. La política de la derecha españolista significaba para Euskadi más paro, más pobreza, más contaminación, más militares, menos libertades, «la división territorial, la negación del derecho de autodeterminación y la marginación del euskera y la cultura vasca» 286 .

Los Partidos nacionalistas, por su parte, eran culpables de haber abandonado la lucha por la integración de Navarra en Euskadi, dejando a los navarros en manos de las fuerzas reaccionarias 287 .

El balance negativo de la última Legislatura autonómica, concretado en la profunda crisis económica e industrial, se atribuyó a la mala gestión de socialistas y nacionalistas en el Gobierno vasco, calificados de «estafadores y terroristas industriales» 288 . Este había demostrado su «incompetencia al no poder gestionar correctamente las migajas recibidas tras mendigar ante el Gobierno de Madrid»289. Socialistas y peneuvistas, además, habían protagonizado un verdadero espectáculo de enfrentamientos y acusaciones durante la campaña después de haberse repartido durante cuatro años las prebendas del sistema político ${ }^{290}$.

282 Ver Correo 8, 23 y Deia 8, 4.

283 Correo 9, 29. Ver también, El Mundo del País Vasco 9, 17.

284 Ver Correo 12, 17.

285 Correo 9, 29.

286 Deia 17, 7. Egin 17, 8, desarrolla ampliamente la denuncia de las fuerzas españolistas y de derechas.

287 Correo 8, 23.

288 Correo 18, 26.

289 Correo 14, 25. Ver también, Deia $11,7$.

290 Ver Deia 22, 9. En Correo 17, 29, se dice: «Arzalluz y Ardanza aparentan estar enfadados con Felipe González, pero el día 24 volverán a pactar». 
Al PNV se le negó su pretensión de mostrar una imagen negociadora de la paz, ya que, además de acatar la Constitución, participaba en «la elaboración de las medidas represivas contra los presos»291. Se le echó en cara una política españolista, diciendo que el PNV utilizaba «a su conveniencia tanto a la Guardia Civil como a la Ertzaintza para atacar a los derechos que nos corresponden como pueblo»292. A estas palabras de Aizpurua siguieron las de Olarra, que responsabilizaron al PNV de dirigir la política represiva del Estado español. «Lo hace - dijo- cuando saca a su brazo armado, la Ertzaintza, contra nosotros; cuando nos censura en su «telebatzoki»; cuando desarrolla una política de españolización, o cuando enseña al PSOE a destruir a los presos» 293 . En su hipocresía, trataba de esconder durante la campaña que era el mejor aliado de la política del PSE; echaba la culpa de todo a Madrid y realizaba una política de derechas, que traía «la crisis económica, el cierre de empresas, los contratos basura y la privatización de la sanidad» 294 . Odiaba a la izquierda abertzale y presentaba candidato por Bizkaia al mejor policía que tenía Madrid en Euskal Herria. «Y éstos — añadía Olarra- nos vienen hablando de paz. Cuánta hipocresía y cinismo» 295 .

La candidatura de Atutxa, por la que Aizpurua sentía vergüenza, había servido para que, por fin, el PNV se quitara la careta y mostrase su verdadera cara, «la de la represión»296. Este aspecto se unía a otro ya denunciado, el abandono de la causa de la independencia del pueblo vasco ${ }^{297}$.

La utilización de Alava para atender las necesidades de Bizkaia y Guipúzcoa y su política clientelista de enchufismo y corrupción sólo habían servido para potenciar el españolismo ${ }^{298}$.

Mediada la campaña, Idígoras advirtió al PNV que su enemigo no era la izquierda abertzale, sino los partidos españolistas de derecha y de izquierda, y le pidió que abandonara «su estrategia de colaboración con

291 Correo 10, 17.

292 Correo 11, 25. Ver también, El Mundo del País Vasco 11, 12.

293 Correo 12, 17

294 Correo 12, 17.

295 Deia 12, 8. En El Mundo del País Vasco 19, 11, se culpa a Ardanza de entorpecer las conversaciones de Argel.

296 Correo 14, 25. En esta intervención de Aizpurua en Bermeo se repiten todas las acusaciones de Olarra contra el PNV y la Ertzaintza.

297 Ver Egin 16, 14, donde Landa echa en cara a los dirigentes del PNV «la grave responsabilidad que están adquiriendo ante todo el pueblo vasco con el mantenimiento de esa estrategia de dinamitar la identidad nacional vasca, participando también en el diseño y la ejecución de medidas de castigo contra presos y exiliados, azuzando a la policía contra la ciudadanía y, en definitiva, realizando el doble juego de palabras de distracción pero hechos de sumisión a la Constitución española y al sistema político impuesto desde el Estado».

298 Ver Deia 14, 9. 
Madrid para debilitar la conciencia abertzale»299. Era tal la actitud del PNV que constituía un obstáculo claro, al igual que el Partido Socialista, para iniciar un proceso de paz. Se trataba de un Partido reaccionario, que, juntamente con el PSE, era responsable «del asentamiento de un modelo social enormemente injusto y desigual» ${ }^{300}$. La política del Gobierno Vasco, como la del Gobierno central, había servido para «enriquecer a los propios ricos y empobrecer a los más necesitados» ${ }^{301}$. Landa pedía juego democrático y libre para poder dabatir todo esto con el PNV, pero el sistema vigente era una democracia útil para el PNV, por ser de derechas, y para el PSOE, por ser español, pero inservible para la izquierda abertzale 302 .

Su política de ikastolas era una agresión contra el movimiento social de las ikastolas y su política general de los diez últimos años había consistido en hacer España de la mano del PSOE, como lo seguiría haciendo cuando ganase el Partido Popular las elecciones, siendo un obstáculo en el camino hacia la soberanía vasca. Iruin dijo del PNV que hacía años había dejado de ser «un nacionalismo reivindicativo para transformarse en un mero nacionalimso de gestión de unas competencias carentes de poder político real» ${ }^{303}$. Por su parte, Idígoras sentenció que «la derecha del PNV, eterna aliada de Madrid, ha conducido a este pueblo a un callejón sin salida, donde la Constitución española es la única norma de aplicación y donde la unidad de todos los españoles es su principal fundamento» ${ }^{304}$.

El PNV tenía una responsabilidad directa en el proceso de desnacionalización de Euskal Herria, porque de su mano estaban entrando tanto el Partido Socialista como el Partido Popular. A pesar de que últimamente el discurso del PNV se acercaba al de HB, lo que prevalecía, según Landa era «su responsabilidad directa en la estrategia represiva del Gobierno español» 305 .

En resumen, el PNV era el Partido que preocupaba a HB, «esa fuerza reaccionaria, profundamente de derechas, antisocial, elitista y clasista, que es el PNV, que se está consolidando en las esferas del poder local» ${ }^{306}$. Por eso, «para el PNV el enemigo natural a batir es la izquierda abertzale» ${ }^{307}$.

299 Correo 15, 21. La negativa de Ardanza a debatir con representantes de HB y su exclusión del debate inicial es interpretado en la misma línea de intentar dañar a la izquierda abertzale (Correo 19, 26).

300 Correo 19, 27. Las mismas críticas en Deia 19, 6.

301 Egin 9, 15.

302 Correo 19, 27.

303 Deia 19, 6.

304 Deia 21, 4. Ver también, El Mundo del País Vasco 21, 13.

305 Deia $15,8$.

306 El Mundo del País Vasco 19, 10.

307 El Mundo del País Vasco 19, 11. La cita completa de las manifestaciones de K. Landa sobre el PNV es la siguiente: «Otra cuestión es la actitud de HB y la izquierda abertzale ante 
A todo lo dicho sobre el Partido Socialista hay que añadir la acusación de que, en cuanto Partido del Gobierno del Estado, era responsable de dirigir las inversiones extranjeras y los fondos europeos fuera de Eus$\operatorname{kadi}^{308}$.

Los dirigentes de Izquierda Unida eran los «recién llegados que (aspiraban) a ocupar el nido de la izquierda vasca, como si hubiesen luchado todos estos años» ${ }^{309}$. «¿Dónde estaba el califa de Córdoba - preguntó Idígoras cuando se votó el Tratado de Maastricht? Sólo HB se opuso a las medidas neoliberales, ya que IU se abstuvo» 310 .

Izquierda Unida necesitaba quitarse la careta, ya que su izquierdismo era igual que el del PSOE, dispuesto a pactar con los conservadores, si le conviniere. No era «ni de izquierdas ni democrático» ${ }^{312}$.

Unidad Alavesa fue calificada de «esperpento español», que defendía «su Alava de peineta rojigualda y sus punzones para pinchar ruedas de coches con matrículas de Bilbao», manifestando con ello su «odio a lo vasco y su deseo de enfrentamiento entre nosotros» ${ }^{313}$.

determinadas fuerzas políticas como el PNV, la derecha reaccionaria que está teniendo una postura enormemente negativa para los sectores populares de Euskal Herria. El PNV está implicado, junto al Gobierno español, en toda una política de consecuencias dramáticas, desastrosas para la población vasca, está implicado en implantar aquí un modelo social antagónico con lo que nosotros queremos hacer, que está generando yuppismo, instalación de determinadas clases que se enriquecen con procesos económicos y políticos, mientras que se produce el empobrecimiento y la marginación de sectores populares amplísismos. El PNV es la derechona vasca y nuestro proyecto se enfrenta al suyo. Por lo tanto, en ese sentido no hay acuerdo entre el PNV y nosotros. Por cierto, además de eso, los grados de implicación del PNV con el Gobierno español a nivel de estrategia represiva manifiestan muy claramente que para el PNV el enemigo natural a batir es la izquierda abertzale. Este partido es muy consciente (sic) de que la izquierda abertzale defiende un modelo para Euskal Herria en el que se acaba su chollo particular, esa es la realidad».

308 Ver Deia 19, 6. También en Egin 19, 11.

309 Correo 17, 19.

310 Correo 18, 26. En Deia 21, 4, se acusa a Anguita de haber firmado los pactos de la Moncloa.

311 Ibidem.

312 E1 Mundo del País Vasco 19, 10.

313 Deia 22, 9. Una síntesis de las ideas generales vertidas en la campaña aparece en la entrevista a Mati Iturralde en Egin 20, 10 y 11. 